\title{
Response of a dryland fluvial system to climate-tectonic perturbations during the Late Quaternary: Evidence from Rukmawati River basin, Kachchh, western India
}

\author{
Archana Das ${ }^{1,2, *}$, Falguni Bhattacharya ${ }^{1}$, B K Rastogi ${ }^{1}$, Gaurav Chauhan ${ }^{2}$, \\ Mamata NGANGOM ${ }^{2}$ and $M$ G ThaKKAR ${ }^{2}$ \\ ${ }^{1}$ Institute of Seismological Research, Raisan, Gandhinagar 382009 , Gujarat, India. \\ ${ }^{2}$ Department of Earth and Environmental Science, K.S.K.V. Kachchh University, Bhuj, Kachchh 370 001, India. \\ ${ }^{*}$ Corresponding author.e-mail: rchndas7@gmail.com
}

Dryland rivers, dominated by short-lived, localised and highly variable flow due to discrete precipitation events, have characteristic preservation potential, which serves as suitable archives towards understanding the climate-tectonic coupling. In the present study, we have investigated the fluvial records of a major, southerly-draining river - the Rukmawati River in the dryland terrain of southern Kachchh, in western India. The sediment records along the bedrock rivers of Kachchh register imprints of the Indian summer monsoon (ISM), which is the major source of moisture to the fluvial system in western India. The Rukmawati River originates from the Katrol Hill Range in the north and flows towards the south, into the Gulf of Kachchh. The field stratigraphy, sedimentology, along with the optical chronology suggests that a braided-meandering system existed during 37 ka period due to an overall strengthened monsoon. A gradual decline in the monsoon strength with fluctuation facilitated the development of a braided channel system between 20 and $15 \mathrm{ka}$. A renewed phase of strengthened monsoon with seasonality after around $15 \mathrm{ka}$ which persisted until around $11 \mathrm{ka}$, is implicated in the development of floodplain sequences. Two zones of relatively high bedrock uplift are identified based on the geomorphometry and morphology of the fluvial landform. These zones are located in the vicinity of the North Katrol Hill Fault (NKHF) and South Katrol Hill Fault (SKHF). Geomorphic expression of high bedrock uplift is manifested by the development of beveled bedrock prior to or around 20 ka during weak monsoon. The study suggests that the terrain in the vicinity of NKHF and SKHF is uplifting at around 0.8 and $>0.3 \mathrm{~mm} / \mathrm{a}$, respectively. Simultaneously, the incision in the Rukmawati River basin, post $11 \mathrm{ka}$, is ascribed to have occurred due to lowered sea level during the LGM and early Holocene period.

\section{Introduction}

Dryland fluvial systems, which operate in ephemeral or intermittent hydrological regime, are considered as sensitive recorders of subtle shifts in climatic conditions (Knighton and Nanson 1997; Reid and Frostick 1997; Tooth 2000 and references therein). Temporal changes in the hydrological condition are manifested in the type and the nature of the sediment transport, channel style and the sedimentary architecture (Nanson and Tooth 1999; Tooth 2000). In dry lands, the erosional effectiveness of precipitation is generally very high, as the rainfall occurs over sparse or uneven vegetation-covered ground surface, leading to significant sediment mobilisation. In view of this, it is argued that the dryland

Keywords. Katrol Hill Fault; OSL chronology; palaeoclimate; tectonic activity; valley fill sediments; Kachchh.

J. Earth Syst. Sci., DOI 10.1007/s12040-016-0733-7, 125, No. 6, August 2016, pp. 1119-1138

(C) Indian Academy of Sciences 
fluvial systems are not sediment limited, instead, they are transport limited (Tooth 2000). Although transport limited, the dryland streams are efficient erosional agents, as sediments of all sizes are readily available for erosion on sparsely vegetated slopes. Due to this, the suspended sediment concentrations and bedload transport rates are typically much higher in dryland streams (Reid and Frostick 1997). For a given intensity, rains in a dryland environment tend to produce more run-offs per unit area, as plant cover and surface organic matter is sparse (Knighton and Nanson 1997). Even though the climate sensitivity of the dryland fluvial system, compared to its humid counterpart, is high, studies pertaining to its response to climate, tectonic and sea-level perturbations are limited (Candy et al. 2004; Waclawik et al. 2008).

It has been observed that the geomorphic response of dryland fluvial system is quite complex (Tooth 2000), but the tectonic influence cannot be much different from the rivers which operate in other climatic domains. For example, if the upland region is undergoing active tectonic deformation, it is reasonable to assume that the sediment delivery from the catchment will be accelerated, thus plugging the down valley. Similarly, if the river valley is undergoing active deformation, incision would lead to the development of terraced landform (Whipple 2004). The arid and semi-arid western India was the focus of research on river response to monsoon variability (Pant and Chamyal 1990; Tandon et al. 1997;
Juyal et al. 2000, 2006; Jain and Tandon 2003; Prasad et al. 2014). Attempt has also been made to deconvolve the climate and tectonic contribution particularly from the northern and central Gujarat alluvial plain (Srivastava et al. 2001; Juyal et al. 2000, 2006) and more recently from the tectonically active Kachchh peninsula (Mathew et al. 2006; Bhattacharya et al. 2013, 2014; Prizomwala et al. 2016b). However, studies pertaining to the comprehensive response of dryland rivers to climatic, tectonic and sea-level perturbations from western India are limited, particularly from Kachchh.

Kachchh peninsula as a whole and the southern Kachchh, in particular, are seismically one of the most active regions in India after Himalaya (figure 1) (Biswas 2005; Patidar et al. 2007; Rastogi et al. 2012). The geomorphic setup of Kachchh indicates a strong structural control on the landscape evolution owing to the presence of several E-W trending faults (Chamyal et al. 2003). Several studies have documented the tectono-geomorphic and palaeoseismological signatures of active faulting from KHF and southern Kachchh mainland (Maurya et al. 2003; Thakkar et al. 2006; Patidar et al. 2007, 2008; Morino et al. 2008; Kundu et al. 2010). Contrastingly, there have been few studies which have documented the climatic signals from the landscape of Kachchh. Maurya et al. (2003) suggested that the fluvial sequences of southern Kachchh mainland have been operating since preLGM and have experienced two aggradation phases

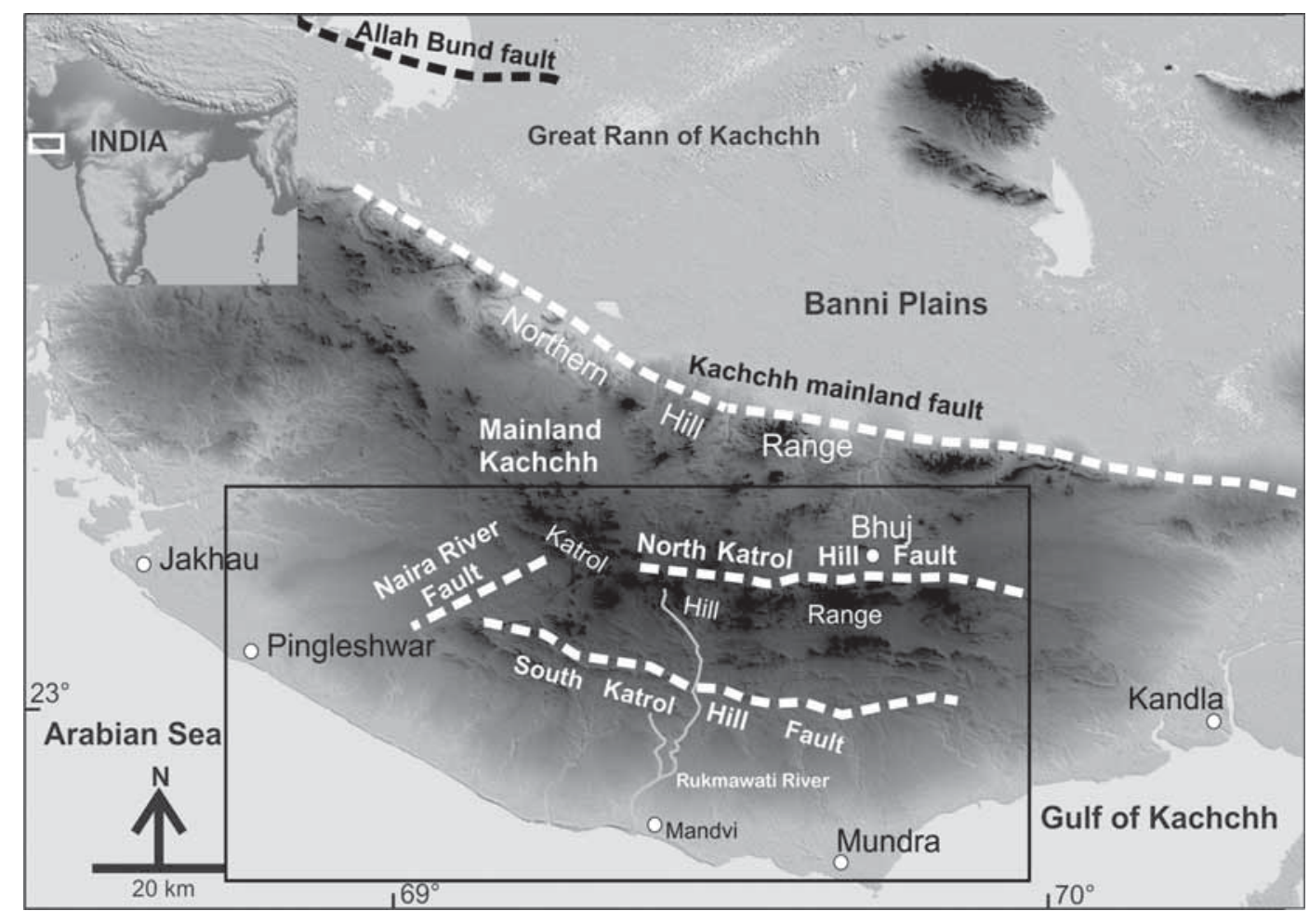

Figure 1. Map of Kachchh showing major faults along with the study area (shown with black rectangle). 
during the Late Pleistocene period and middle-tolate Holocene punctuated by two phases of incision, viz., during the early and late Holocene. Recent study invokes progressive strengthening of monsoon during Late Pleistocene (17-12 ka) followed by fluctuating but strengthened monsoons during early Holocene (12-8 ka) and a declining monsoon strength towards the Late Holocene $(\sim 3 \mathrm{ka})$ (Bhattacharya et al. 2013, 2014).

Considering the above, the southern Kachchh mainland appears to be a potential area for addressing the much-debated question of climatic, tectonic and sea-level interplay during the Late Quaternary period. Although few studies exist (Maurya et al. 2003; Patidar et al. 2007; Bhattacharya et al. 2013, 2014), the present study is a contribution towards improving our understanding of climate-tectonic interaction in the evolution of the dryland fluvial landforms. More specifically, the objectives are:

- To ascertain the fluvial response to Late Quaternary climate fluctuations.

- To understand the sediment transfer mechanism with respect to climate variability, uplift and sealevel changes in dryland rivers.

\section{Study area}

In the present study, we have investigated the southern flowing Rukmawati River which originates from the southern slopes of the Katrol Hill Range (KHR) and is delimited by the scarp of the Katrol Hill Fault (KHF) in the north. KHF is a reverse fault dipping towards south (Chung and Gao 1995; Maurya et al. 2003). The scarp associated with KHF can be divided into NKHF (North Katrol Hill Fault) and SKHF (South Katrol Hill Fault) (figure 1). SKHF is a younger and relatively smaller scarp, located $\sim 15-20 \mathrm{~km}$ south of the NKHF (Maurya et al. 2003; Patidar et al. 2007). Based on the anomalous increase in river incision, earlier researchers (Maurya et al. 2003; Patidar et al. 2007) have suggested that the SKHF is a splay of the main KHF (i.e., NKHF), which outcrops in the south, in the form of a distinct scarp (figure 1).

The Kachchh region experiences a semi-arid to arid climate with rainfall occurring from Indian summer monsoon (ISM) during June and September. The annual precipitation in the region is less than $300 \mathrm{~mm}$ (Pramanik 1952; Sontakke et al. 2008). The vegetation is dominated by thorny bushes and shrubs.

\section{Geomorphology and geomorphometric parameters}

Geomorphologically, the Rukmawati River can be divided into the following four major zones.
- The northern rocky uplands consisting of domes and Mesozoic sandstone and shale dominated hills

- Piedmont zone fringing the domes and hills

- Ravines in the piedmont/alluvial plain

- The southern alluvial plain (figure 2)

The middle reach of the river constitutes the Deccan Trap (basalt) which is traversed by the SKHF (Maurya et al. 2003). Conspicuous presence of ravines over the pedimont and alluvial surfaces demarcates the southern part of SKHF (figure 2). In the lower reaches, the Rukmawati River flows through the alluvial zone before debouching into the Gulf of Kachchh (figure 2).

Recently, Das et al. (2016) reported the geomorphic evidence of SKHF using geomorphometric parameters pertaining to active tectonics. In the present study, we have evaluated the tectonic activity along NKHF using routinely used geomorphometric parameters (Keller and Pinter 1996; Das et al. 2016; Prizomwala et al. 2016a). We have estimated the mountain front sinuosity of a segment of the mountain front, north of the origin of Rukmawati River, following the methodology suggested in Das et al. (2016). Similarly, we have estimated stream length gradient index (SL Index) along the trunk stream of the Rukmawati River to evaluate the spatial differential uplift experienced in the upper, middle and lower segments of the Rukmawati River (Keller and Pinter 1996; Das et al. 2016). Figure 3 shows spatial variations of SL index along various segments of the Rukmawati River basin and the mountain front sinuosity along the fronts of NKHF and SKHF. It has been observed that higher SL value is associated with the convex upward nature of the longitudinal river profile of the Rukmawati River.

\section{Valley-fill stratigraphy}

The valley fill sequences in the Rukmawati River can be traced from rocky uplands and right up to the coastal alluvial plains. In this study, three representative sections, viz., at

- Rampar Vekra located south of the NKHF,

- Asambia Gangaji located south of the SKHF, and

- Kodai in the alluvial zone, have been explored for sedimentological and chronometric studies (figure 2).

\subsection{Rampar Vekra}

At Rampar, a $\sim 9.2 \mathrm{~m}$ thick sedimentary sequence is exposed (figures 4 and 5), which overlies the exposed beveled Mesozoic bedrock (9 m thick). On 


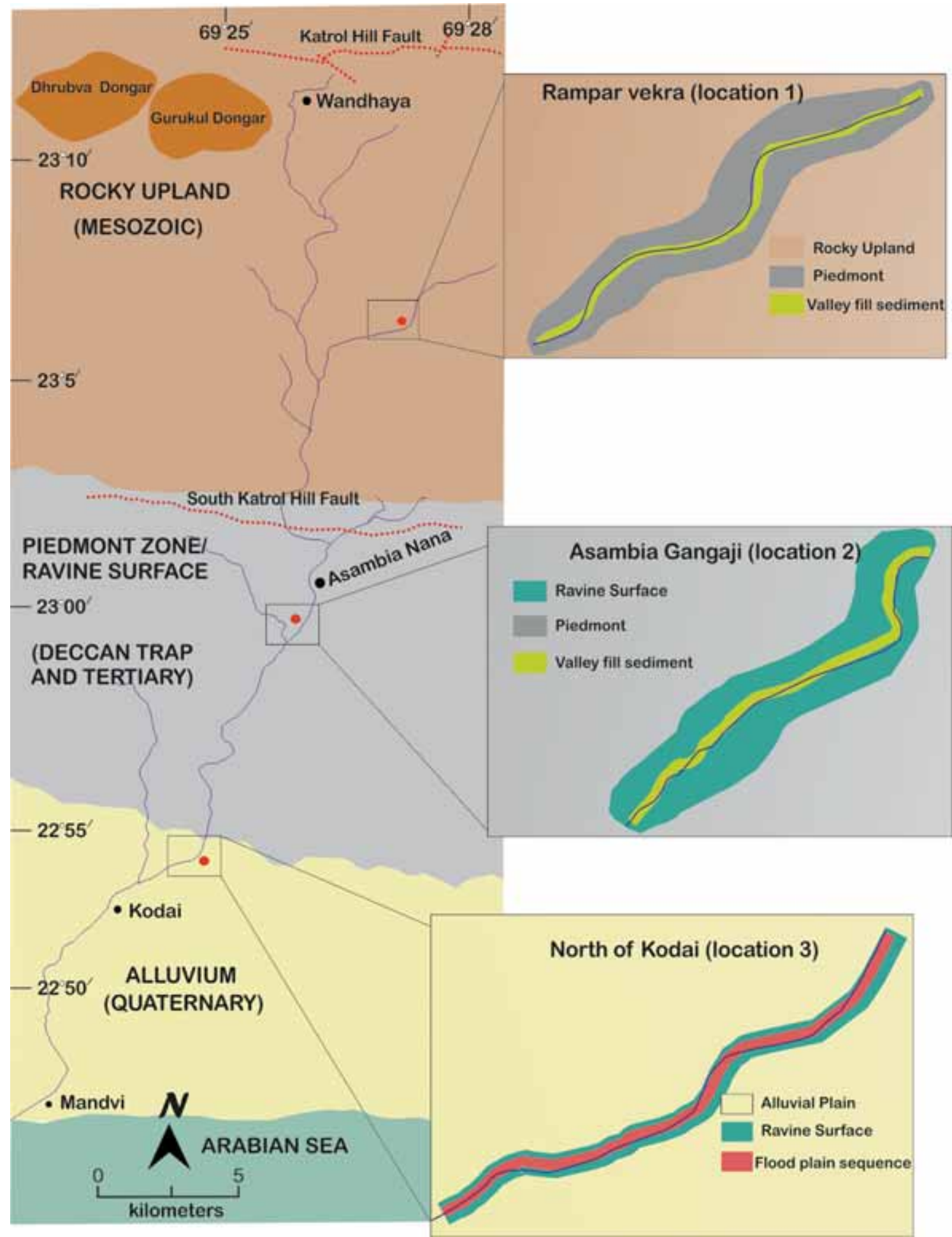

Figure 2. Geomorphological map showing rocky upland, piedmont zone with ravine surfaces and alluvium deposits along the Rukmawati River originating from Katrol Hill Fault and traversing towards the Arabian Sea. Faults are marked with red dotted lines. (a) Enlarged segment of Rampar Vekra (location-1), (b) enlarged segment of Gangaji Mandir (location-2), and (c) enlarged segment of the north of Kodai (location-3).

the basis of grain size, fabric, sedimentary structures and sorting, various sedimentary units are identified. Based on the sediment characteristics, the sediment succession can be divided into nine units, following the sedimentary facies classification of
Miall (1996). These sediments are divisible into five sedimentary facies and the facies identified are: clast supported gravel $(\mathrm{Gcm})$, massive sand $(\mathrm{Sm})$, planar cross stratified sand $(\mathrm{Sp})$, trough cross stratified sand (St) and horizontally stratified 


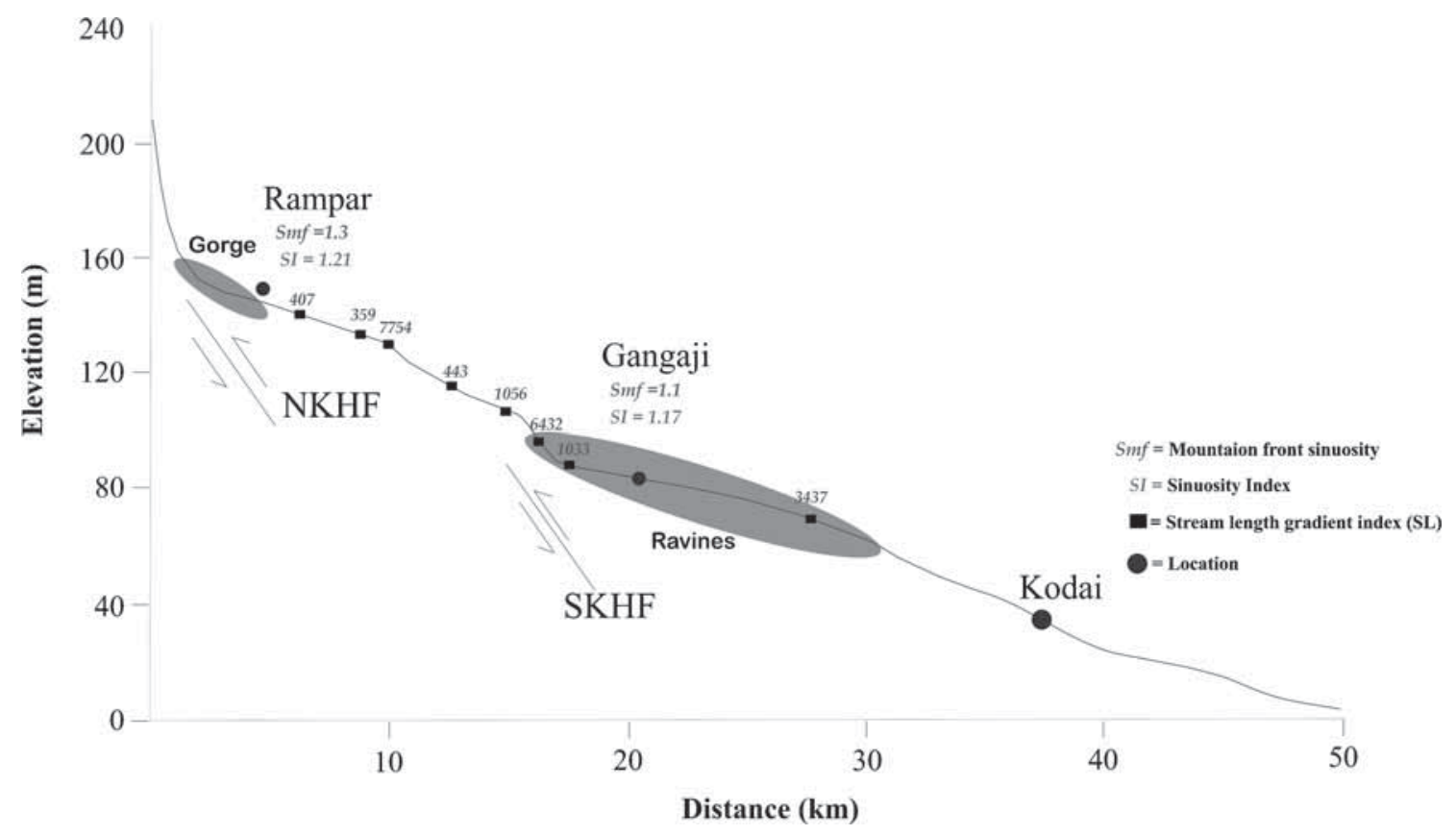

Figure 3. Longitudinal river profile of the Rukmawati River basin with tectono-geomorphic features. Black circles showing OSL sample location and basin showing tectono-geomorphic features with geomorphometric values for the river.

sand (Sh). From the bottom upwards, the sediment succession began with the deposition of $30-\mathrm{cm}$ thick angular to sub-angular clasts supported gravelly horizon which are randomly distributed (Gcm facies; unit-1). The clasts are mainly composed of Mesozoic sandstone, which is ferruginous in nature. Overlying this horizon is a $120-\mathrm{cm}$ thick planar cross stratified coarse to medium sand $(\mathrm{Sp})$ with occasional angular lithoclast, deposited parallel to the bedding plane (unit-2). The horizon is overlain by $20-\mathrm{cm}$ thick crudely laminated fine sand (Sh) with discrete gravels (unit-3). At places, the horizon shows mottling. This is followed by a $40-\mathrm{cm}$ thick, randomly-oriented, angular and platy lithoclast of sandstone (unit-4). No obvious grading has been observed. The horizon is similar to the Gcm (clast supported gravel) facies of Miall (1996). This is succeeded by a $110-\mathrm{cm}$ thick crudely laminated coarse sand (Sh), comprising of a 40-cm thick endurated clay layer in the lower part of the horizon, whereas in the upper part, friable rhizoliths and diffused carbonate can be observed (unit-5). The horizon shows post-depositional mottling. The horizon is overlain by $100-\mathrm{cm}$ thick miliolitic sand (Sm) which is endurated in the upper part (unit-6). The sand is poorly sorted and does not show any grading. In the upper part, friable rizoliths can be seen. A 50-cm thick trough cross stratified gritty miliolitic sand (St) overlies this horizon which also contains the platy lithoclast (unit-7). Overlying this, is 200-cm thick massive miliolitic sand (Sm) containing dispersed nodular calcrete (unit-8). The sediment succession terminates with the deposition of $250-\mathrm{cm}$ thick crudely laminated miliolitic sand (Sh) with platy lithoclast (unit-9).

\subsection{Asambia Gangaji}

At this location, a 9.5-m thick alluvium succession rests over 6.5-m thick incised Deccan Trap. Based on the textural characteristics a total of six units have been recognized in the field (figures 4 and 6). A total of four facies are identified and the principal facies are: clast supported gravel $(\mathrm{Gcm})$, matrix supported gravel (Gmm), planar cross stratified sand (Sp) and horizontally stratified sand (Sh). From bottom upwards, the sediment succession began with the deposition of 250 -cm thick clast-supported massive gravel horizon (Gcm facies, unit-1) dominated by angular to sub-rounded basalt lithoclast. The maximum size of the lithoclast that has been observed is $25 \mathrm{~cm}$. This horizon is overlain by $160-\mathrm{cm}$ thick, crudely laminated gravelly sand unit (Sh facies, unit-2) with subordinate basalt and sandstone lithoclast. This is succeeded by $100-\mathrm{cm}$ thick, crudely laminated gritty sand (Sh facies, unit-3) horizon comprising of dispersed angular lithoclast. At places, smaller platy and sub-rounded lithoclast are seen. This is overlain by $330-\mathrm{cm}$ thick, coarse to medium sand with intervening angular to sub-rounded platy lithoclast dominated gravelly horizon ( $\mathrm{Gmm}$ facies, unit-4). It has been observed that the clasts are poorly sorted and are embedded in a coarse 


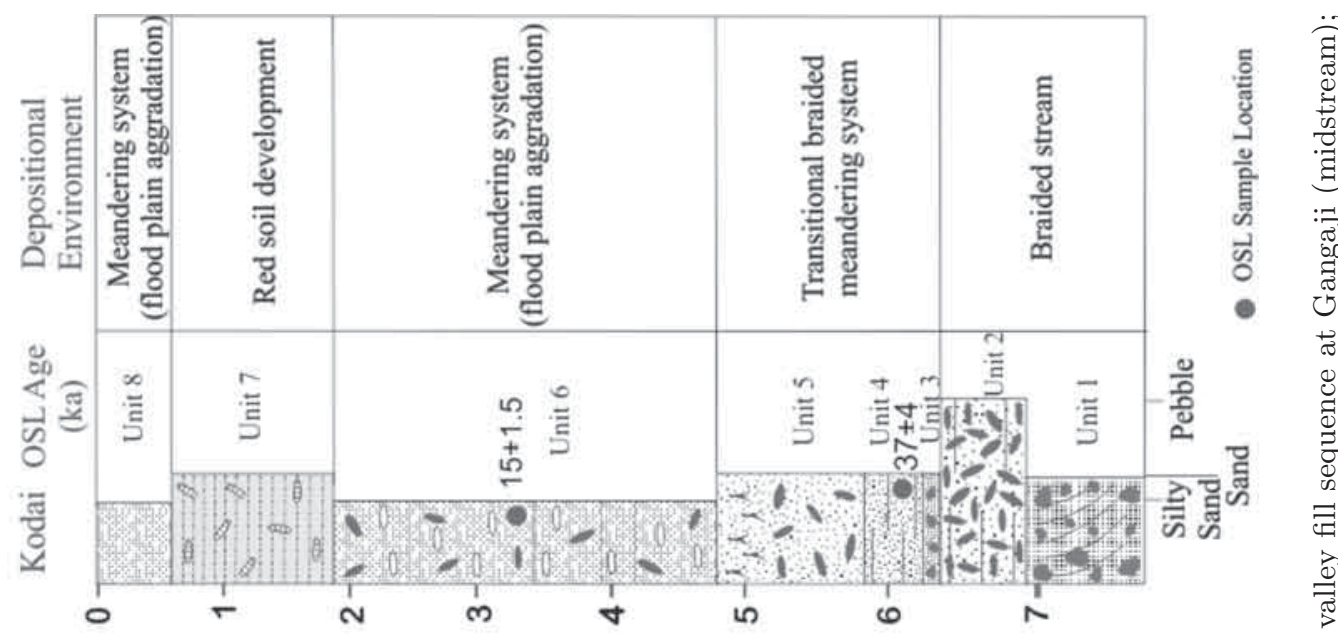

(ui) पıdəa

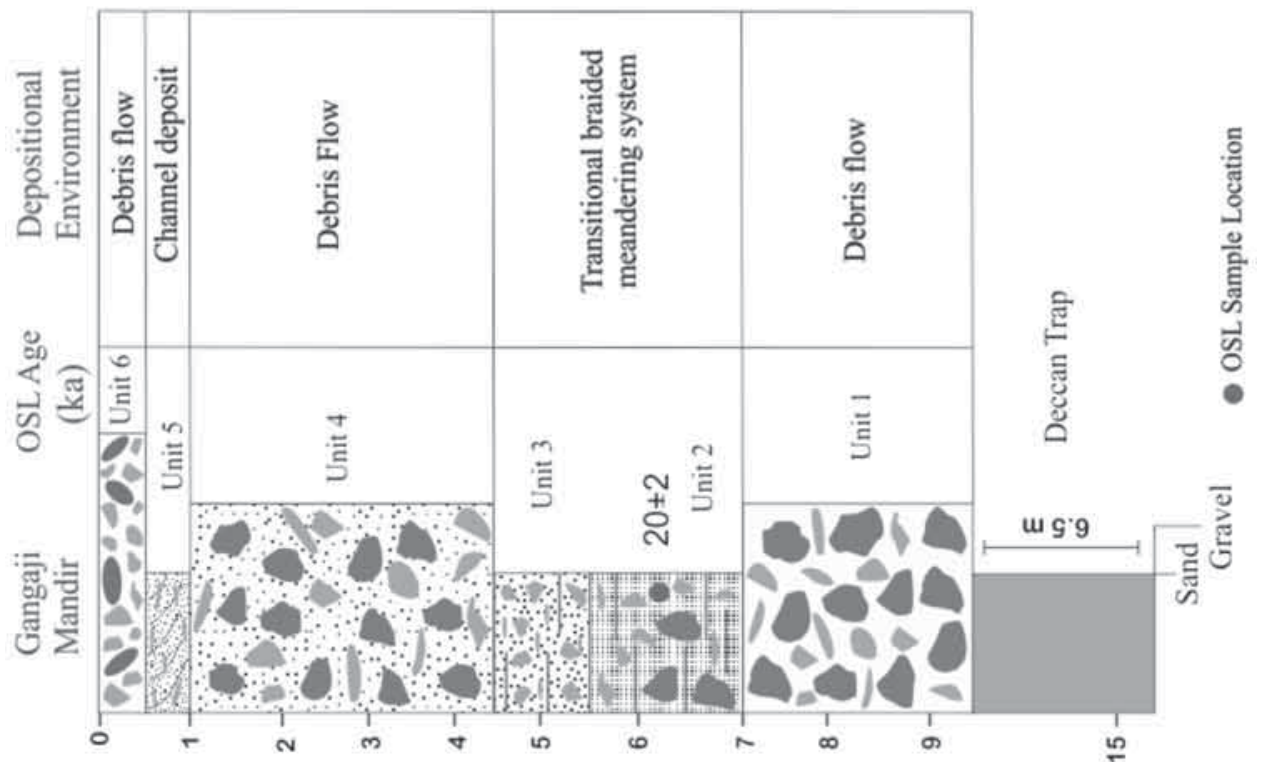

(u) पıdə्व

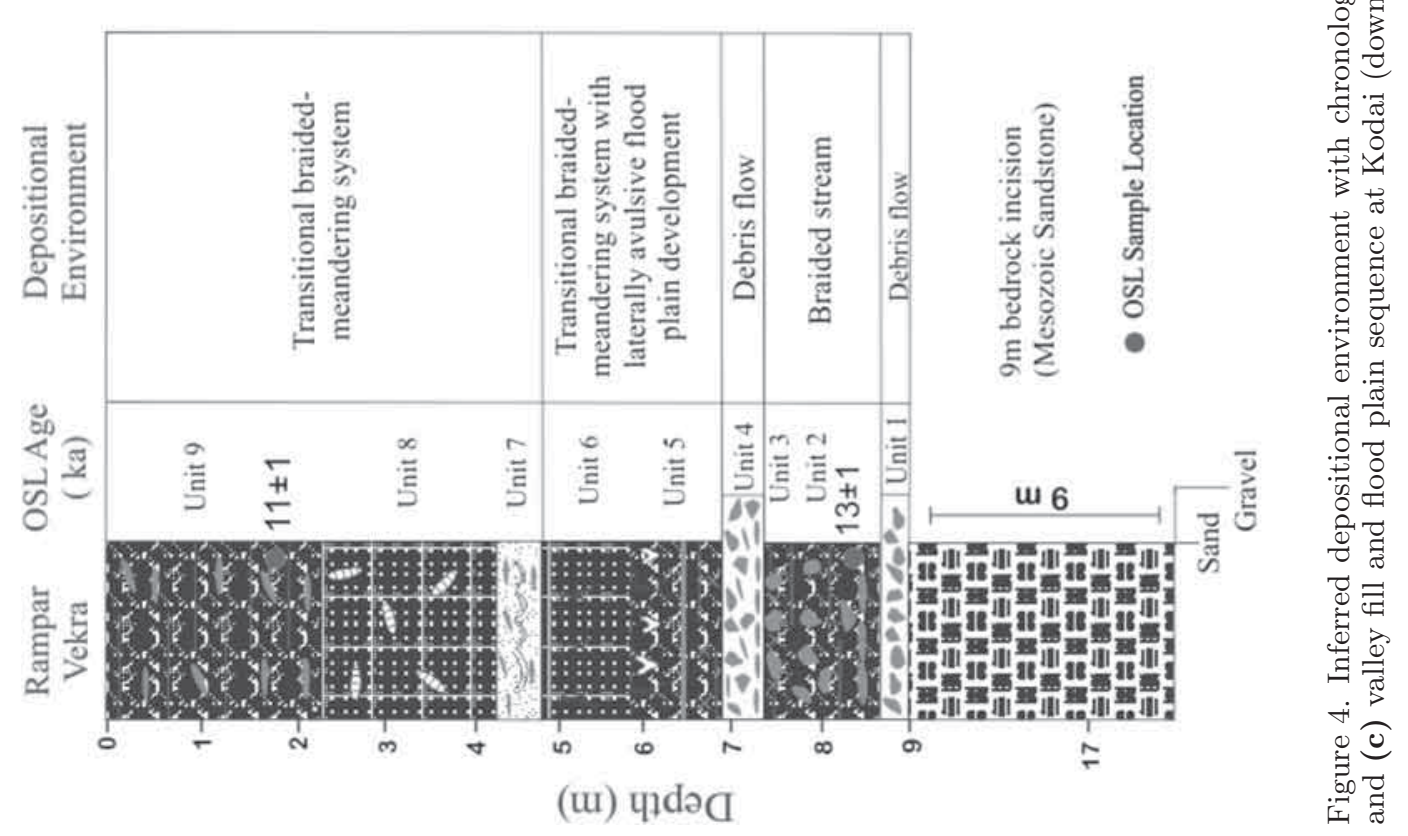




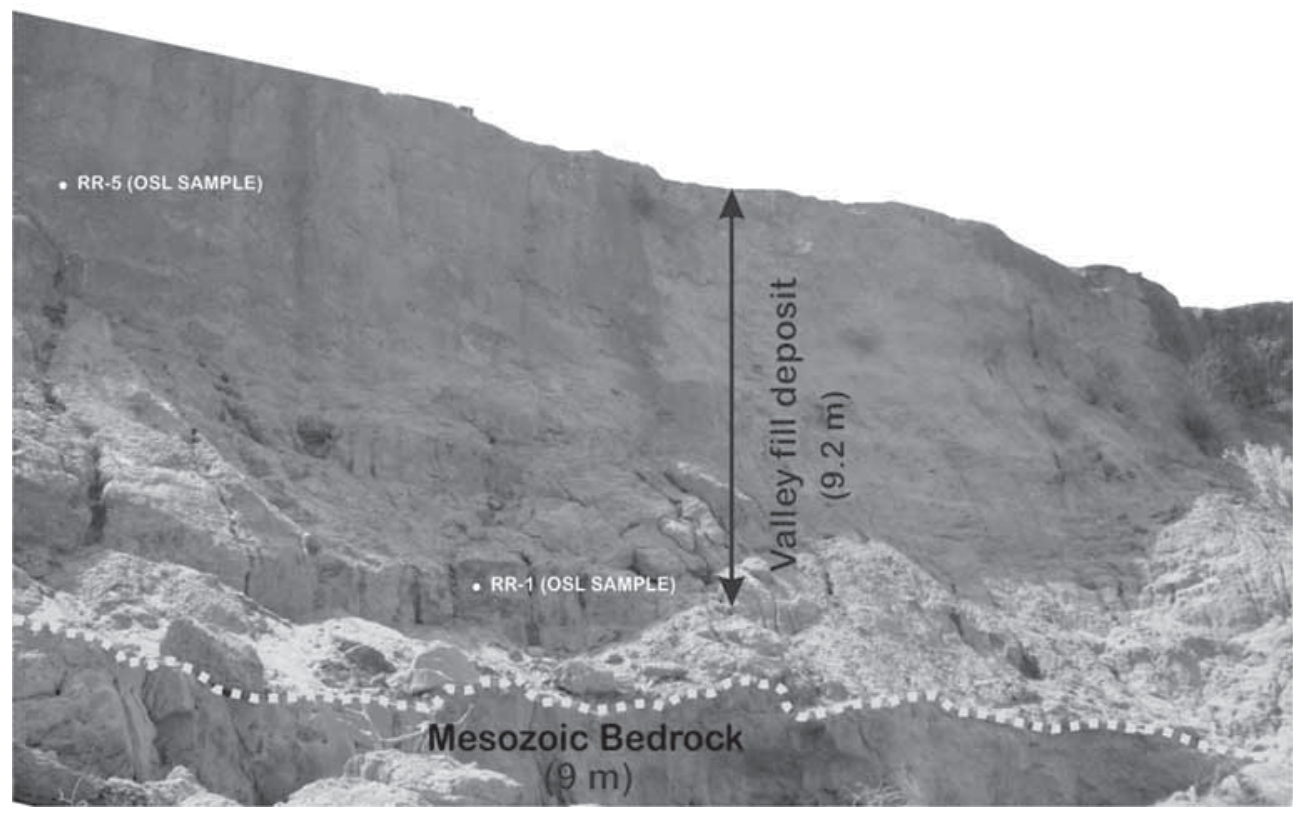

Figure 5. Field photograph showing incised valley fill sequence of Rampar Vekra in the south of NKHF; yellow dotted line delineates the Mesozoic bedrock from the overlying valley-fill deposits with OSL sample locations.

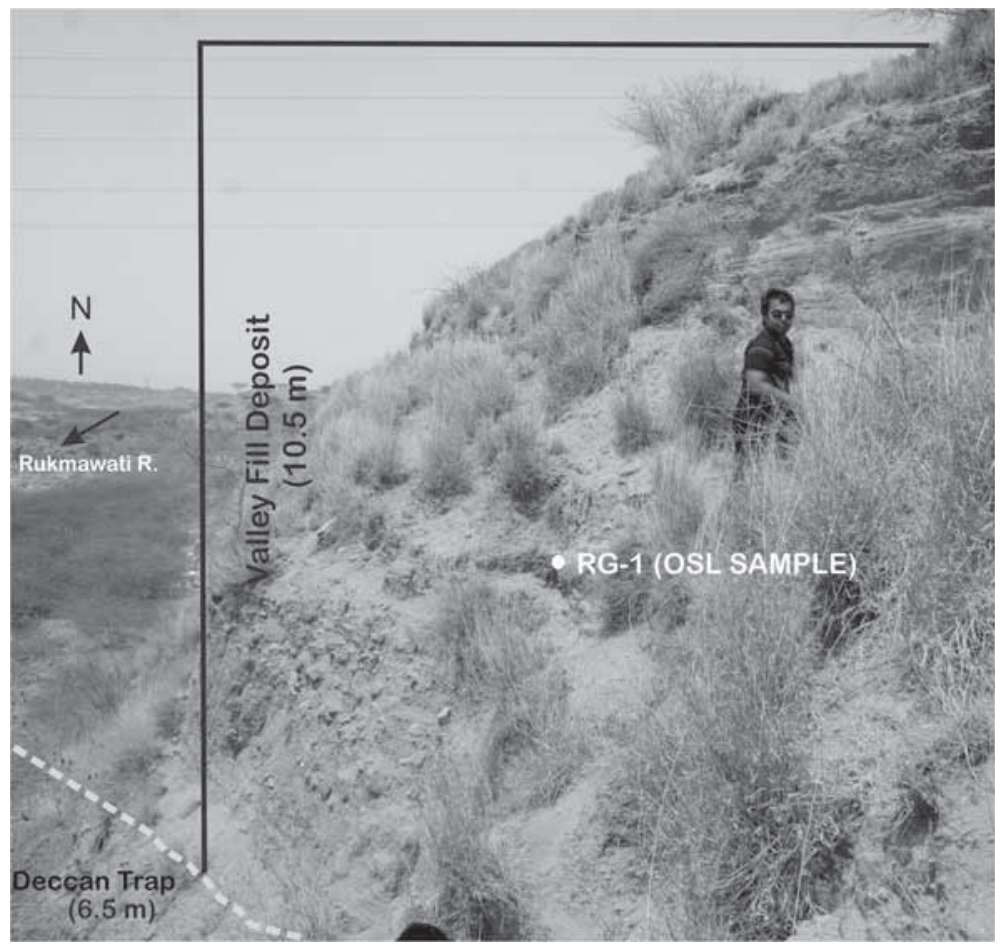

Figure 6. Field photograph showing incised valley fill sequence of Gangaji in the south of SKHF with OSL sample locations.

sandy matrix. Overlying this is a $60-\mathrm{cm}$ thick planar cross-stratified miliolitic gritty sand ( $\mathrm{Sp}$ facies, unit-5) horizon comprising of platy lithoclast. Finally, the sediment succession terminates with the deposition of 50-cm thick, clast supported angular to sub-rounded platy lithoclast dominated horizon (Gcm facies, unit-6) with occasional basalt pebble.

\subsection{Kodai}

At this location, a 7.1-m thick sedimentary succession is investigated. Based on the sedimentary structure, eight units were identified and four principal lithofacies were classified following (Miall 1996). The principal lithofacies are: horizontally stratified sand (Sh), planar cross stratified sand (Sp), 


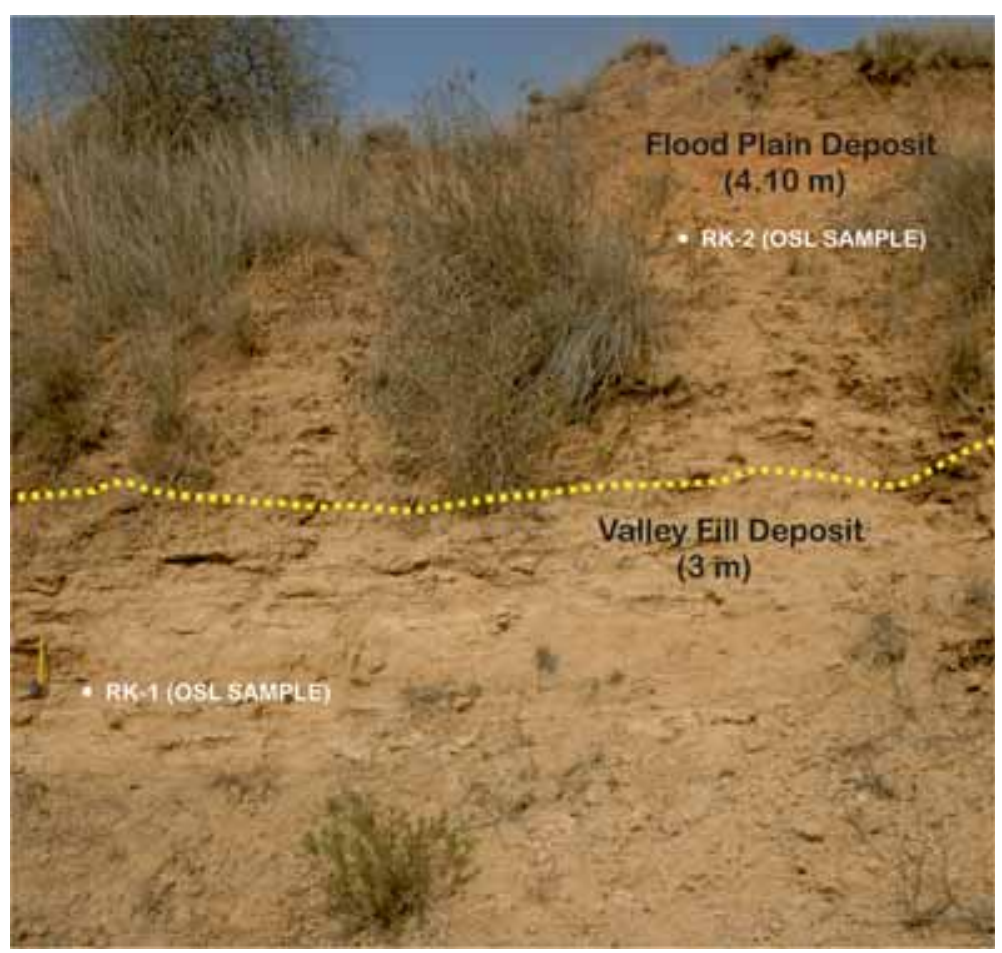

Figure 7. Field photograph showing valley fill and flood plain sequence of Kodai with OSL sample 1 (RK1) from the channel fill deposit; yellow dotted line delineates the two sequences and flood plain sequence of Kodai with OSL sample 2 (RK2).

Paleosol horizon (P) and overbank or abandoned flood plain deposits (FI). From the base upwards, the sequence starts with the deposition of an $80-\mathrm{cm}$ thick cross stratified gravelly sand horizon (Sp facies, unit-1) with occasional boulders (figures 4 and 7). The gravelly sand is overlain by a $60-\mathrm{cm}$ thick crudely laminated sandy pebble horizon (Sh facies, unit-2). This horizon is succeeded by discrete layers of $\sim 10$-cm thick gravely sand horizon (Sh facies, unit-3). Overlying this is a $40-\mathrm{cm}$ thick gritty crudely laminated sand horizon (Sh facies, unit-4). This is succeeded by a $100-\mathrm{cm}$ thick gritty and pebbly sand horizon (Ss facies, unit-5) with weakly developed friable rhizoliths in the upper part of this unit. This unit is overlain by a $260-\mathrm{cm}$ thick compact, moderately pedogenised silty sand (FI facies, unit-6) comprising of moderately developed bedded calcretes with faint parallel lamination. This is succeeded by a $110-\mathrm{cm}$ thick highly weathered red soil horizon (P facies, unit-7) dominated by nodular calcrete with occasional rhizoliths. The sequence terminates with the deposition of a 50-cm thick moderately weathered buff-coloured silty sand layer.

\section{Depositional environment}

\subsection{Rampar Vekra}

The clast supported gravel lying above the beveled planar bedrock represents erosional contact. The beveling of the bedrock occurs due to change in the ratio of the vertical to the lateral erosion which is a characteristic of the down-cutting river in a tectonically active terrain (Hancock and Anderson 2002; Bhattacharya et al. 2014). The beveling takes place during periods of low sediment supply (Lave and Avouac 2001), which provides accommodation space for the valley-fill aggradation. Deposition of angular to sub-angular clasts dominated gravel (unit-1) indicates deposition under high sediment water ratio similar to debris flows (Garzione et al. 2003; Dorsey and Roering 2006) (table 1, figure 4). In a dry land fluvial system, such flows are generated by episodic rainout events which mobilise the sediments from poorly vegetated catchment during drier climatic conditions (Juyal et al. 2006). Deposition of 120$\mathrm{cm}$ thick coarse to medium planar cross-stratified sand (unit-2) indicates improved hydrological condition facilitating transport of sediment flux from the catchment. Planar cross stratified sand can be interpreted as channel bar facies, deposited under lower flow regime (Hein and Walker 1977). The presence of the platy lithoclast indicates an occasional contribution from the proximal slopes. The overlying crudely laminated fine sand (unit-3) suggests gradual improvement in the hydrological conditions. Mottled sand suggests that the sediments were sub-aerially exposed (oxidation) before the deposition of the overlying horizon (unit-4). Deposition of poorly organised angular 
Table 1. Sedimentary facies, characteristics and inferred fluvial processes at Rampar Vekra.

\begin{tabular}{|c|c|c|c|}
\hline $\begin{array}{l}\text { Unit (from } \\
\text { bottom) }\end{array}$ & $\begin{array}{c}\text { Facies } \\
\text { name }\end{array}$ & Characteristics & $\begin{array}{l}\text { Inferred fluvial } \\
\text { processes }\end{array}$ \\
\hline Unit-1 & Gcm & $\begin{array}{l}\text { Angular to sub-angular clasts supported gravelly horizon. The } \\
\text { clasts are mainly composed of Mesozoic sandstone. }\end{array}$ & Debris flow \\
\hline Unit-2 & Sp & $\begin{array}{l}\text { Planar cross stratified coarse to medium sand with occasional } \\
\text { angular lithoclast. }\end{array}$ & Braided channel system \\
\hline Unit-3 & Sh & $\begin{array}{l}\text { Crudely laminated fine sand with discrete gravels. At places } \\
\text { the horizon shows mottling. }\end{array}$ & Braided channel system \\
\hline Unit-4 & Gcm & $\begin{array}{l}\text { Randomly oriented angular and platy lithoclast of Mesozoic } \\
\text { sandstone. }\end{array}$ & Debris flow \\
\hline Unit-5 & Sh & $\begin{array}{l}\text { Crudely laminated coarse sand with mottling in the lower } 40 \mathrm{~cm} \\
\text { which is capped by clay endurated layer. The upper part shows } \\
\text { friable rhizoliths and diffused carbonate. }\end{array}$ & $\begin{array}{l}\text { Braided channel system } \\
\text { with laterally avulsive } \\
\text { flood plain development }\end{array}$ \\
\hline Unit-6 & $\mathrm{Sm}$ & $\begin{array}{l}\text { Ferruginous miliolitic sand with thick sand endurated layer in the } \\
\text { upper part. The unit also shows friable rhizoliths in the upper part. }\end{array}$ & $\begin{array}{l}\text { Meandering channel } \\
\text { system }\end{array}$ \\
\hline Unit-7 & St & Trough cross stratified gritty miliolitic sand with platy lithoclast. & $\begin{array}{l}\text { Braided channel system } \\
\text { with flash flood deposit } \\
\text { for short-span period }\end{array}$ \\
\hline Unit-8 & $\mathrm{Sm}$ & $\begin{array}{l}\text { Massive endurated fluvially reworked miliolitic sand } \\
\text { with dispersed nodular calcrete. }\end{array}$ & $\begin{array}{l}\text { Meandering channel } \\
\text { system }\end{array}$ \\
\hline Unit-9 & Sh & Crudely laminated miliolitic sand containing platy lithoclast. & Braided channel system \\
\hline
\end{tabular}

and platy lithoclast in the unit-4 suggests flash flood condition or short-lived intense precipitation and contribution from valley proximal source. Texturally, this unit suggests that the sediments were transported as debris flows (Iverson 1997; Griffiths et al. 2004). The overlying crudely laminated mottled coarse sand (unit-5) suggests re-establishment of the improved hydrological condition with seasonality. The presence of endurated clay suggests floodplain environment, implying lateral avulsive channels. The occurrence of rhizolith in the upper part is indicative of vegetative cohesive banks (Juyal et al. 2000). The presence of diffused carbonates in association with rhizolith can be ascribed to weak soil forming event on the laterally avulsive flood plain (Kraus 1997). It has been observed from unit-6 to unit-9 that sediments are dominated by miliolite sand. Kachchh miliolites are primarily deposited by aeolian processes (Mathur 2005) and are subsequently reworked by fluvial process under varying hydrological conditions (Bhattacharya et al. 2013). Therefore, the massive miliolite sand with rhizoliths (unit-6) and nodular calcretes (unit-8) can be interpreted as deposition under flashy hydrological conditions (transitional braided-meandering system) (table 1, figure 4). In view of this, textural discrimination was not attained (Thomas et al. 2007). The intervening trough cross-stratified miliolite (unit-7) indicate short-lived flashy events (braided channel). Generally, sediment mobilisation occurs on the rising limb of the flood hydrograph (scouring) and the sediment deposition occurs during the recession phase of the flood (filling). Such scours and fills give rise to cross-stratification in the dryland fluvial environment (Hassan 1990; Tooth 2000). The uppermost crudely laminated platy lithoclast dominated unit-9 indicates gradual weakening in the hydrological condition (initiation of dryness).

\subsection{Gangaji Mandir}

The Gcm facies resting over the incised Deccan Trap represents an erosional contact. The deposition of angular to sub-angular clast dominated gravel (unit-1), indicates deposition under high sediment water ratio environment similar to debris flows (table 2, figure 4). In an arid and semiarid environment, where the catchment areas are poorly vegetated, rivers can erode and transport large volumes of mixed sediments throughout episodic storms. Such events lead to braided channel systems. The higher content of bigger clast size, texture and absence of sedimentary structures, indicate cohesion-less, non-viscous pseudoplastic debris flow, resulting in the deposition of poorly graded massive gravel (Dorsey and Roering 2006; Pope et al. 2008). The angular nature of the clasts confirms the short distance transport from the SKHF (Maurya et al. 2003). The presence of crudely laminated coarse sand with gravels and lithoclast in unit-2 implies deposition under aqueous condition. The deposition of discrete gravel with lithoclast in unit-2 suggests occasional mobilisation of sediments from poorly vegetated proximal areas during episodic rain-out events as 
Table 2. Sedimentary facies, characteristics and inferred fluvial processes at Gangaji Mandir.

\begin{tabular}{|c|c|c|c|}
\hline $\begin{array}{l}\text { Unit (from } \\
\text { bottom) }\end{array}$ & $\begin{array}{c}\text { Facies } \\
\text { name }\end{array}$ & Characteristics & $\begin{array}{l}\text { Inferred fluvial } \\
\text { processes }\end{array}$ \\
\hline Unit-1 & Gcm & $\begin{array}{l}\text { Clast-supported massive gravel horizon dominated by angular to } \\
\text { sub-rounded basalt lithoclast. }\end{array}$ & Debris flow \\
\hline Unit-2 & Sh & $\begin{array}{l}\text { Crudely laminated gravelly sand unit with subordinate basalt and } \\
\text { sandstone lithoclast. }\end{array}$ & Braided channel system \\
\hline Unit-3 & Sh & $\begin{array}{l}\text { Crudely laminated gritty sand horizon containing dispersed } \\
\text { angular lithoclast. At places, smaller platy and sub-rounded } \\
\text { lithoclast are seen. }\end{array}$ & Braided channel system \\
\hline Unit-4 & $\mathrm{Gmm}$ & $\begin{array}{l}\text { Coarse sandy gravelly horizon with angular to sub-rounded platy } \\
\text { lithoclast dominated horizon. }\end{array}$ & Debris flow \\
\hline Unit-5 & $\mathrm{Sp}$ & $\begin{array}{l}\text { Planar cross-stratified miliolitic gritty sand horizon containing } \\
\text { platy lithoclast. }\end{array}$ & Braided channel system \\
\hline Unit-6 & Gcm & $\begin{array}{l}\text { Clast supported angular to sub-rounded platy lithoclast dominated } \\
\text { horizon with occasional basalt pebble. }\end{array}$ & Debris flow \\
\hline
\end{tabular}

hyper-concentrated flow deposits (Miall 1996). The overlying crudely laminated gritty sand with platy lithoclast in unit-3 suggests gradual improvement of the hydrological conditions. Erratic occurrences of imbricated platy lithoclasts indicate transportation under an aqueous environment (shortdistance) during improved flow condition. The overlying matrix supported sandy gravel (unit-4) suggests their deposition during a short-lived storm surge flood event from the proximal slopes. This reflects the formation of this lithofacies by the process of high strength hyper-concentrated flow deposits containing sediment in the range of 20$60 \%$ by volume (Miall 1996; Garzione et al. 2003; Dorsey and Roering 2006; Pope et al. 2008). Such gravels are associated with ephemeral flows and represent advancing channel bars. The deposition of planar cross-stratified miliolitic sand (unit-5), indicates improved hydrological conditions with well-regulated sediment flux from the catchment. The planar cross stratified sand can be interpreted as channel bar facies, deposited under lower flow regime (Hein and Walker 1977). The overlying clast supported gravel (unit-6), indicates debris flow deposits containing about $60-65 \%$ sediment by volume (Wasson 1979; Miall 1996), implying weak hydrological conditions. The presence of subordinate pebbles in unit-6 indicates that adequate differentiation in grain size before the floods spilled over the banks (Thomas et al. 2007). Therefore, deposition seems to have occurred as braided seasonally high discharge bedload stream during the weakening of hydrological conditions.

\subsection{Kodai}

From bottom upward, the planar cross stratified gravelly sand (unit-1) indicates good hydrological conditions with fluctuations (table 3, figure 4). The planar cross stratified sand can be interpreted as channel bar facies deposited under lower flow regime (Hein and Walker 1977). The presence of gravels (unit-1) with occasional boulders implies a sudden increase in the sediment supply during episodic storm surge events. The overlying crudely laminated pebbly sand (unit-2) indicates good hydrological conditions with high discharge and sediment supply. However, the presence of sub-rounded pebbles in unit-2 indicates that inadequate textural segregation in the main channel before the floods spilled over the banks (Thomas et al. 2007) with episodic flood events. The overlying sandy horizon (unit-3) and crudely laminated gritty sand (unit-4) suggests gradual improvement of the hydrological conditions with seasonality. The deposition of discrete gravels in unit-4 suggests their deposition during a short-lived storm surge flood event from the surrounding slopes. The gravel clasts in sandy lithofacies indicate transport and deposition by sheet floods in braided stream channels (Aziz et al. 2003; Kallmeier et al. 2010). The deposition of gritty sand with intercalations of pebbles in unit-5 suggests improved hydrological conditions. The presence of pebbles implies high magnitude flood events from the proximal source. The occurrence of rhizoliths in the upper part of the unit suggests vegetative cohesive banks (Juyal et al. 2000). The deposition of pedoginized silty sand in unit- 6 and 8 indicate moderate energy condition with the transformation from braided to meandering channel and sudden weakening of flows leading to deposition of silt (Schumm and Brakenridge 1987) owing to continuous rainfall, well-vegetated catchments and riverbanks (Miall 1996). The occurrence of faint parallel laminations is due to the settling within the slack water conditions. The occasional association 
Table 3. Sedimentary facies, characteristics and inferred fluvial processes at Kodai.

\begin{tabular}{|c|c|c|c|}
\hline $\begin{array}{l}\text { Unit (from } \\
\text { bottom) }\end{array}$ & $\begin{array}{c}\text { Facies } \\
\text { name }\end{array}$ & Characteristics & $\begin{array}{l}\text { Inferred fluvial } \\
\text { processes }\end{array}$ \\
\hline Unit-1 & $\mathrm{Sp}$ & $\begin{array}{l}\text { Planar cross stratified gravelly sand horizon with occasional } \\
\text { boulder. }\end{array}$ & Braided channel system \\
\hline Unit-2 & Sh & Crudely laminated sub-rounded sandy pebble horizon. & Braided channel system \\
\hline Unit-3 & $\mathrm{Sh}$ & Discrete layers of gravelly sand horizon. & $\begin{array}{l}\text { Transitional braided - } \\
\text { meandering system }\end{array}$ \\
\hline Unit-4 & Sh & Crudely laminated gritty sand horizon. & $\begin{array}{l}\text { Transitional braided - } \\
\text { meandering system }\end{array}$ \\
\hline Unit-5 & Ss & $\begin{array}{l}\text { Gritty and pebbly sand horizon containing weakly developed } \\
\text { friable rhizoliths in the upper part of this unit. }\end{array}$ & Braided channel system \\
\hline Unit-6 & FI & $\begin{array}{l}\text { Compact, moderately pedogenised silty sand containing moderately } \\
\text { developed bedded calcretes having faint parallel lamination. }\end{array}$ & $\begin{array}{l}\text { Meandering channel } \\
\text { system with flood plain } \\
\text { aggradation }\end{array}$ \\
\hline Unit-7 & $\mathrm{P}$ & $\begin{array}{l}\text { Highly weathered red soil horizon dominated by nodular calcrete } \\
\text { with occasional rhizoliths. }\end{array}$ & Red soil development \\
\hline Unit-8 & FI & Moderately weathered buff-coloured silty sand. & $\begin{array}{l}\text { Meandering channel } \\
\text { system with flood plain } \\
\text { aggradation }\end{array}$ \\
\hline
\end{tabular}

of bedded calcretes implies groundwater fluctuation in a riverine setting (Goudie 1983; Juyal et al. 2006). Therefore, these two units can be attributed to post-depositional weathering caused due to persistent and prolonged sub-areal exposures due to the existence of a laterally avulsive fluvial system. Deposition of red soil horizon with nodular calcretes (unit-7) suggests low energy environment, enhanced moisture availability with relatively distal overbank environments, influenced by prolonged sub-aerial exposure. An overall predominance of floodplain development indicates that the rivers are mixed load meandering type.

\section{Optical chronology}

A total of five sedimentary units (i.e., unit-2 and 8 at Rampar Vekra; unit-2 at Gangaji Mandir and unit- 4 and 6 at Kodai (figure 4)) were sampled for OSL dating. Typically, about 100 aliquots were measured from each unit and out of these, around 20-25 satisfy the criterion of a recycling ratio within $10 \%$ of unity. The post-depositional mixing and heterogeneous bleaching due to significant variability in sediment-water ratio (discussed above) during the fluvial transport may lead to the presence of more than one dose population (Srivastava et al. 2001). In order to extract the best estimate of the burial dose, statistical models such as the Central Age Model (CAM) of Galbraith et al. (1999) and the Minimum Age Model (MAM) proposed by Galbraith and Laslett (1993) were employed. In the present study, all the samples were analysed using MAM except for the sample RR1, where, since the overdispersion was $<30 \%$,
CAM was used. Finally, radial plots were prepared to illustrate the precision on the dose estimates (Galbraith et al. 1999) (figure 8). The growth curve (9a, c and e) and shine down curve (9b, d and f) for three samples (RR1, RG1 and RK1) is also prepared (figure 9). At Rampar Vekra, the bottom-most unit- 2 is dated to $13 \pm 1$ ka and unit8 is dated to $11 \pm 1 \mathrm{ka}$ (figure 4 ). At Gangaji, the lowermost unit-2 gave an age of $20 \pm 2 \mathrm{ka}$ (figure 4) and at Kodai, the lowermost unit- 4 is dated to $37 \pm$ 4 ka whereas the unit- 6 is dated to $15 \pm 1.5 \mathrm{ka}$ (figure 4 ). The details of radioactivity, dose rate, equivalent dose and ages are given in table $4(\mathrm{a}$ and $\mathrm{b})$.

\section{Discussion}

\subsection{Paleoenvironment}

Unlike the lacustrine record, where sedimentological evidence of climate variability is nearly continuous, the fluvial records are always discrete and only the high magnitude and regionally extensive events get preserved. In view of this, the climatic events reconstructed based on fluvial archives are based on those events which were basin-wide and persisted over multi-millennial year time scale (Juyal et al. 2006). The chronometric data supported by detailed field stratigraphy and sedimentology indicate that the river has preserved the sedimentary record spanning the later part of MIS-3 (37 ka) to the early Holocene (11 ka) (figure 4). The sedimentological characteristics of the oldest preserved sequence dated to 37 ka suggest deposition under overall strengthened ISM with fluctuations (figure 10). These periods correspond to the later 


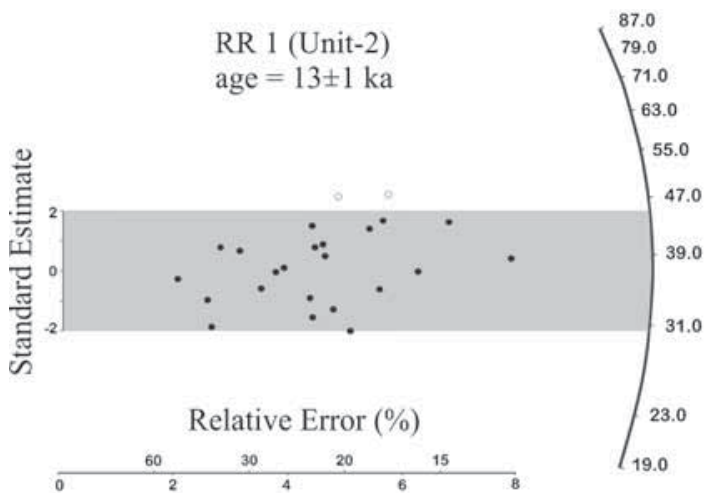

(a)

Precision

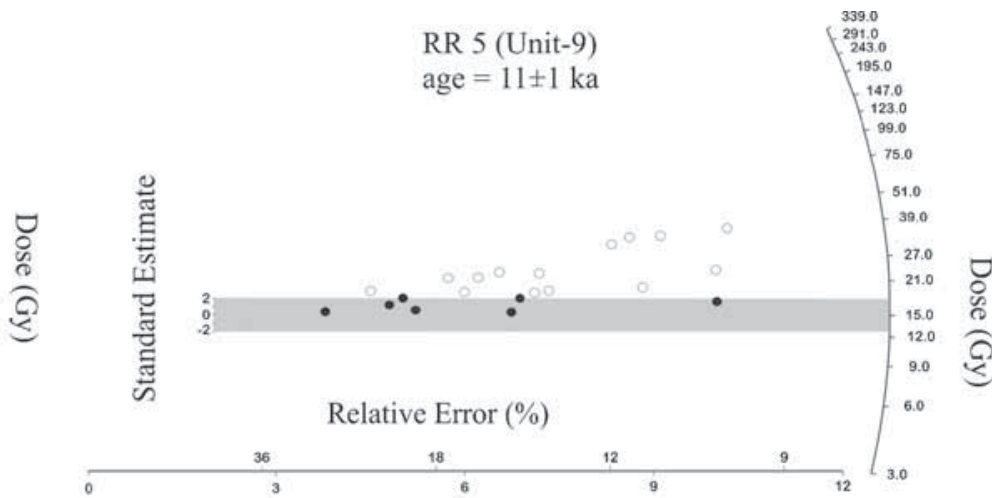

(b)

Precision

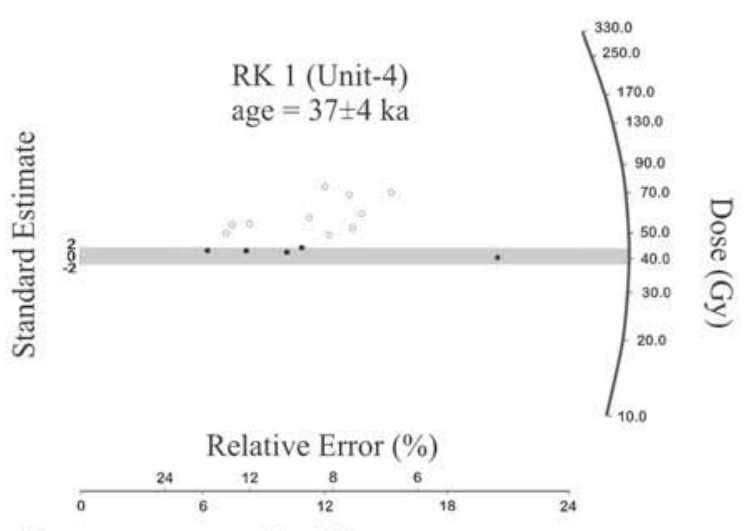

(d)

Precision

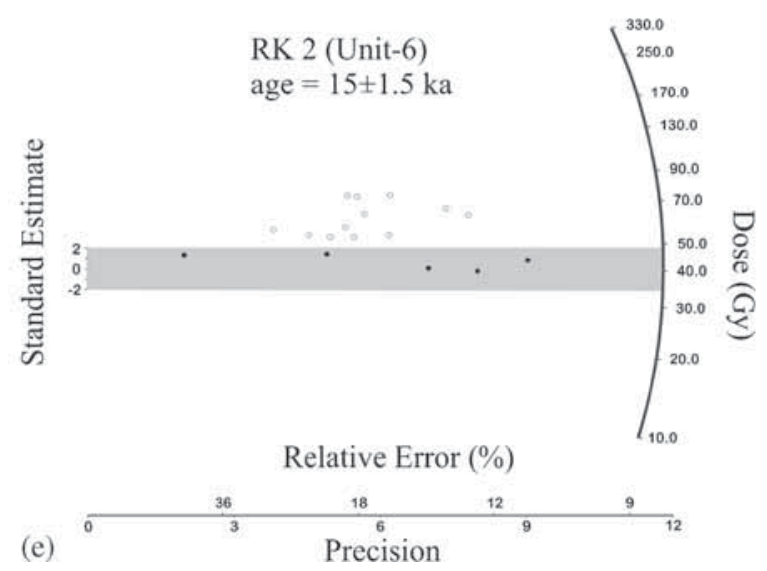

Figure 8. Radial plots showing the De distribution for all the five samples in the present study.

part of the pluvial MIS-3 and is well represented in many fluvial sequences both in the arid and semiarid regions (Tandon et al. 1997; Juyal et al. 2000, 2006), western India (Kale and Rajaguru 1987) and central India (Singh et al. 1999; Srivastava et al. 2001). Following this, declining monsoon strength has been inferred, which implies river metamorphosis from the relatively confined system (meandering) to frequently avulsive hydrological condition with sediment supply, outpacing the river carrying capacity (dominantly braided). Optical chronology suggests that river metamorphosis began after the end of MIS-3 and probably continued until around the LGM. Field observations along with the optical chronology suggest insignificant sediment aggradation in the study area after the MIS-3 and before the LGM (figure 4). The absence of fluvial sediments could either be due to limited sedimentmobilisation, because of gradual declining in ISM strength or the subsequent improved ISM condition after the LGM eroded the sediment from the river basin. We tend to speculate the former as a likely possibility. Following the MIS-3, and with the onset of glacial maximum, the terrain witnessed large-scale sediment mobilisation in the form of sediment gravity flow (debris 


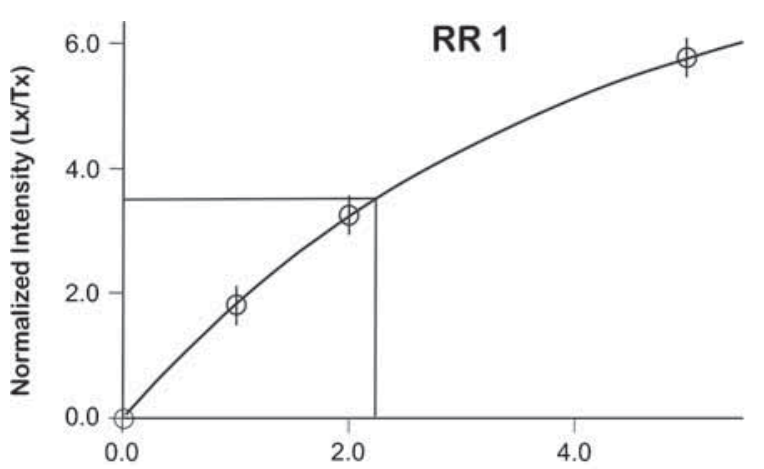

(a)
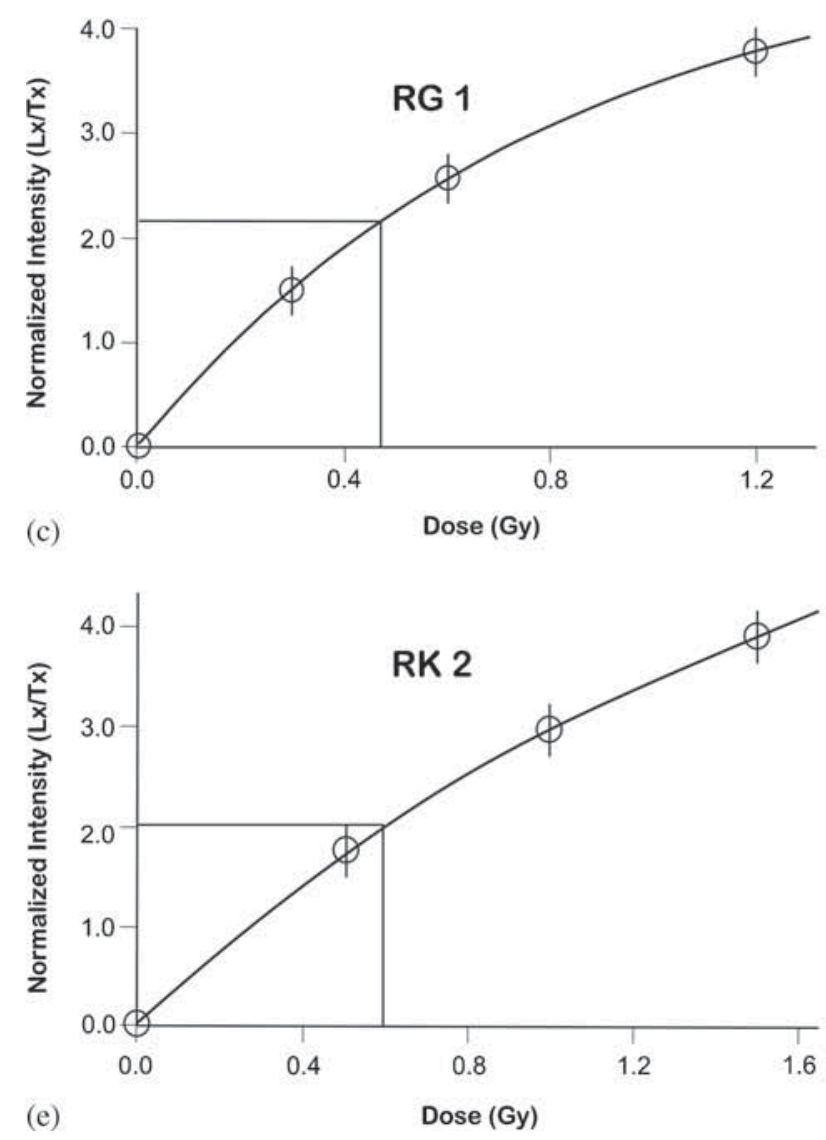
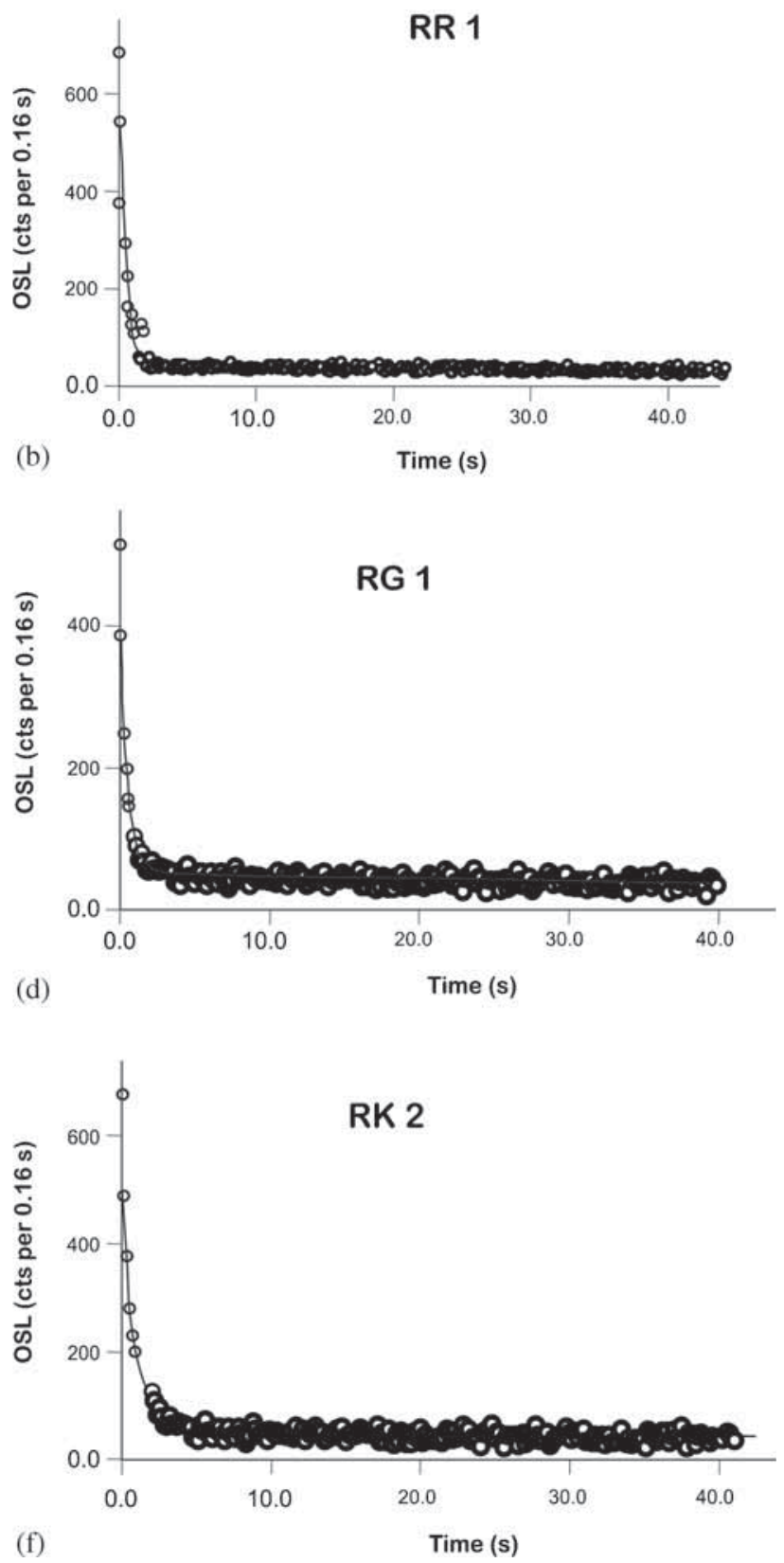

(f)

Figure 9. Typical growth curves (a, c and e) and shine down curves (b, d and f) for three samples (RR1, RG1 and RK1).

flow). Considering that ISM was weak during the LGM (Duplessy 1982; Prell and Kutzbach 1987), storm surge events caused short-distance convective moisture laden storm cells, which locally mobilise the sediments without appreciable sorting. These large-scale mobilisations of sediments were carried out most likely due to the abrupt short period high magnitude discharges and/or aided by tectonic uplifts. A similar observation was made by Bhattacharya et al. (2013, 2014) from the north-flowing rivers in the study area. The onset of the ISM with gradual strengthening is inferred based on well graded, relatively fining, upward sediment sequence which is dated between
15 and 11 ka (figure 4). Bhattacharya et al. (2014) have also reported a progressive strengthening of the monsoon between 17 and $12 \mathrm{ka}$ and an overall strengthened monsoon with fluctuation between 12 and $<8 \mathrm{ka}$. This deposition has occurred in a flood plain environment, suggesting cohesive river banks of a meandering fluvial system with occasional flooding (Juyal et al. 2000). This regional event of strengthening of monsoon has been reported in western India and central India apart from studies from the western Himalayas. The palaeomonsoonal proxies show fluctuations from humid to dry phases during 14.7-12.5 ka periods, which follows the LGM. The Arabian Sea record of 
Table 4. (a) Details of radioactivity and dose rate obtained using Single Aliquot Regeneration (SAR) methods. (b) Palaeodose and ages obtained using CAM and MAM methods.

(a)

\begin{tabular}{lcccccc} 
Locations & \multicolumn{1}{c}{} & \multicolumn{3}{c}{ Cosmic ray dose } \\
Kodai & Sample no. & $\mathrm{U}(\mathrm{ppm})$ & Th $(\mathrm{ppm})$ & $\mathrm{K}(\%)$ & rate $(\mu \mathrm{Gy} / \mathrm{a})$ & Dose rate $(\mu \mathrm{Gy} / \mathrm{a})$ \\
Gangaji & Unit-4 (RK1) & $1.05 \pm 0.05$ & $6.09 \pm 0.3$ & $0.41 \pm 0.01$ & $198 \pm 9$ & $1256 \pm 56$ \\
Kodai & Unit-2 (RG1) & $1.49 \pm 0.07$ & $10.7 \pm 0.5$ & $0.87 \pm 0.02$ & $198.4 \pm 14$ & $1900 \pm 94$ \\
Rampar Vekra & Unit-2 (RR1) & $2.11 \pm 0.1$ & $17.8 \pm 0.8$ & $1.08 \pm 0.03$ & $198 \pm 9$ & $2638 \pm 142$ \\
Rampar Vekra & Unit-9 (RR5) & $1.17 \pm 0.05 \pm 0.1$ & $12.9 \pm 0.64$ & $1.62 \pm 0.05$ & $119 \pm 12$ & $2783 \pm 113$ \\
& & $6.46 \pm 0.3$ & $0.69 \pm 0.02$ & $119 \pm 12$ & $1373 \pm 54$
\end{tabular}

(b)

\begin{tabular}{lccccc} 
Locations & Sample no. & CAM De (Gy) & MAM De (Gy) & CAM age (ka) & MAM age (ka) \\
\hline Kodai & Unit-4 (RK1) & $77 \pm 4$ & $41 \pm 4$ & $69 \pm 5$ & $37 \pm 4$ \\
Gangaji & Unit-2 (RG1) & $74 \pm 4$ & $38 \pm 3$ & $39 \pm 3$ & $20 \pm 2$ \\
Kodai & Unit-6 (RK2) & $77 \pm 4$ & $41 \pm 3.5$ & $29 \pm 2$ & $15 \pm 1.5$ \\
Rampar Vekra & Unit-2 (RR1) & $37 \pm 1$ & $20 \pm 1$ & $13 \pm 1$ & $7 \pm 1$ \\
Rampar Vekra & Unit-9 (RR5) & $34 \pm 2$ & $15 \pm 1$ & $24 \pm 2$ & $11 \pm 1$ \\
\hline
\end{tabular}

Water content $(\mathrm{wt} \%)=10 \pm 2$.

G. bulloids also points towards a similar inference of around $14.5 \mathrm{ka}$ (Overpeck et al. 1996). A nearcontinuous fluvial aggradation in the Alaknanda valley was dated between 15 and 7 ka which was attributed to an enhanced monsoon (Juyal et al. 2010).

Based on the composite log (figure 10), the present study summarises that the fluvial sedimentation has commenced around $37 \mathrm{ka}$ and continued until around $11 \mathrm{ka}$. An overall strengthened monsoon during $37 \mathrm{ka}$ led to the development of a braided meandering system that persisted around 33 ka. A gradual declining monsoon with fluctuations, facilitated the development of braided channel system between 20 and $15 \mathrm{ka}$. Around $15 \mathrm{ka}$, an enhanced monsoon with seasonality led to the development of a meandering system which facilitated the development of floodplain aggradation. During 15-13 ka, the declining monsoon facilitated the development of an avulsive system with red soil development. The onset of ISM with fluctuations, around $13 \mathrm{ka}$, led to the deposition of braided meandering system which gradually declined in the monsoon during $11 \mathrm{ka}$.

Interestingly, in the north-flowing rivers, fluvial sediment aggradation continues until around $3 \mathrm{ka}$ (Bhattacharya et al. 2013). However, in the present study, the termination of the aggradation event and subsequent initiation of incision of the fluvial sequences remain speculative due to limited chronology (absence of terrace tread age). Also, the sediment packages, in the present study, at all the three respective locations are different. Therefore, they are not laterally correlatable, which is due to the different depositional environments. This is possibly due to their location in different geomorphological and tectonic terrain. For example, the upstream site at Rampar is bounded by NKHF and SKHF scarp; this segment shows the formation of incised strath surface owing to uplift along these fault block. The middle part, Gangaji, is fringed by only the SKHF scarp in the north, which is similar to the Rampar site, which led to the formation of a strath surface. On the contrary, the lowermost Kodai site is located on the alluvial plain (figure 2), which is showing widespread valley aggradation and is the site where the oldest sediments have been preserved. The presence of these faults and differential activity along them could be the reason for the inconsistency in the lateral facies variations in the study area.

\subsection{Fluvial response to tectonic activity}

The tectonically active nature of the northern part of the Katrol Hill Fault Range has been explicitly discussed by earlier researchers (Rajenderan and Rajenderan 2001; Patidar et al. 2007; Morino et al. 2008; Kundu et al. 2010; Rastogi et al. 2012). However, the tectonic scenario along the southern part of the Katrol Hill Fault Range comprising the present study area is least investigated. The results of the geomorphic indices of active tectonics indicate low values of mountain front sinuosity (1.31.1), low values of sinuosity index $(1.2-1.1)$ and abrupt, higher values of stream length gradient index (7754-6432) at Rampar and Gangaji along the NKHF and SKHF respectively (figure 3). In addition to these, the presence of deeply incised ravines along the NKHF and SKHF scarps also suggests a strong tectonic control in the evolution of the valley landscape (figures 2 and 3 ).

Our study indicates that the beveling of the bedrock occurred prior to, or around the age 20 ka (figure 4), which corresponds to the weak 


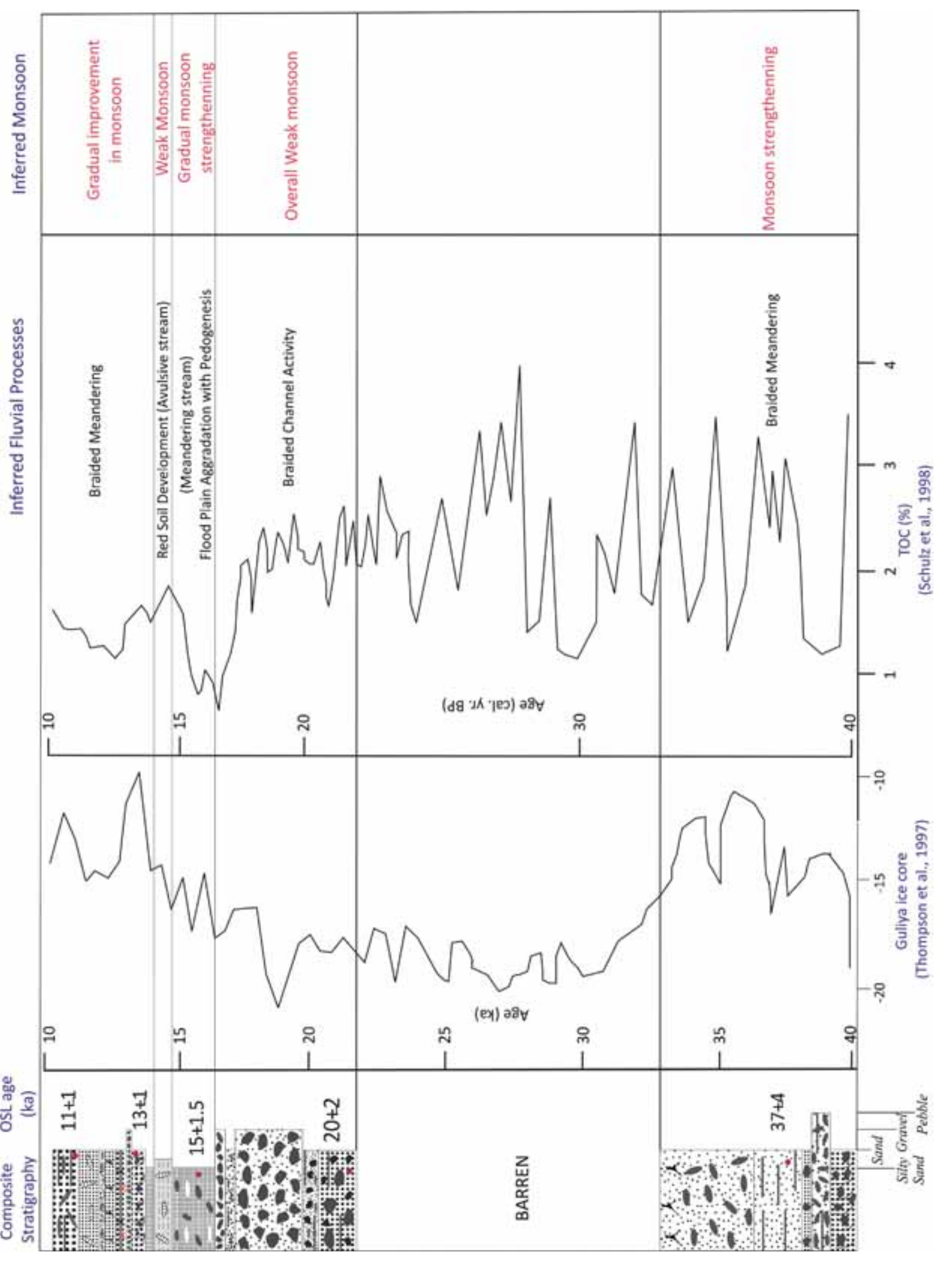

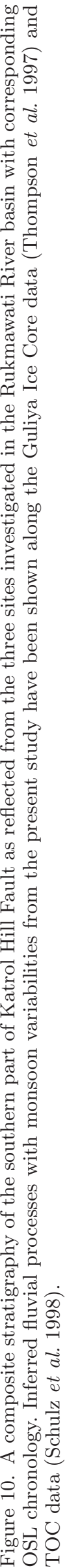


ISM (Duplessy 1982). Similar evidence has also been recorded from the northern Katrol Hill fault (Bhattacharya et al. 2014). The bedrock strath terraces are considered as one of the ideal expressions of the tectonic activity and can be used to estimate the uplift rate (Avouac 2003), which can be estimated by dividing the strath elevation with the youngest age. This method provides the time averaged long-term uplift rate (Lave and Avouac 2001). In the present study, incision rate estimation based on terrace treads has been avoided, as the treads do not mimic the slope of the underlying strath and is conveniently subjected to modification by post-depositional colluvial burial or fluvial dissection that cumulatively increase the modification with terrace age (Knox 1975; Burbank et al. 1996; Eppes et al. 2008). At the upstream segment of Rampar Vekra, the uplift rate, obtained by using the upper-most age of $11 \mathrm{ka}$ (unit-9), is $\sim 0.8 \mathrm{~mm} / \mathrm{a}$. However, (the middle reaches) in case of the Gangaji Mandir site, in the absence of topmost age, $20 \mathrm{ka}$ obtained at a depth of $\sim 6 \mathrm{~m}$ is considered as the age for the deposition of the entire sequence, which is used for the estimation of uplift rate. This is reasonable, considering that the sediments are dominated by the debris flow, suggesting rapid sedimentation. The uplift rate at this location is estimated to be at least $\sim 0.3 \mathrm{~mm} / \mathrm{a}$. The above estimates are on the lower side compared to the observations made by Bhattacharya et al. (2014) along the valley and channel-fill sequences in the Khari and Gunawari rivers which are 3.1 and $4 \mathrm{~mm} / \mathrm{a}$, respectively. The lower uplift rate in the study area as compared to the northern part (proximal to the KHF) may be due to the differences in the estimation methodology. Bhattacharya et al. (2014) have considered total incision thickness, which gives incision rate, whereas we only used strath thickness, which gives a minimum uplift rate.

\subsection{Sea-level influence}

The effect of sea-level changes on the coastal zones of Kachchh has been studied by earlier researchers (Gupta 1975; Maurya et al. 2008). The sea-level fluctuations in the western Indian coastal margin have been compared with the glacio-eustatic sealevel changes (Fairbanks 1989; Chauhan et al. 1993; Hashimi et al. 1995; Lambeck and Chappell 2001; Rao et al. 2003). Based on radiocarbon dates of the relict carbonate deposits, it was suggested that the sea-level was $\sim 100 \mathrm{~m}$ lower than the present during $20 \mathrm{ka}, \sim 30 \mathrm{~m}$ lower during 40-10 ka, $25 \mathrm{~m}$ lower during $11 \mathrm{ka}$ and at $35 \mathrm{~m}$ lower during $14.3 \mathrm{ka}$ (Rao et al. 2003) (figure 11). The base level lowering of rivers in response to the eustatic sea-level lowering can influence the river valley to around $80 \mathrm{~km}$ upstream of the coastline (Miall 1988; Schumm 1993; Blum and Valastro 1994; Koss et al. 1994). Based on the bathymetric contours (figure 11), it may be suggested that more than $100 \mathrm{~km}$ shelf area was exposed in the past, leading to the exposure of the Gulf of Kachchh. In this scenario, the lowering of the sea during the LGM and early Holocene would have contributed to the incision process, particularly in the Rukmawati River basin, which is merely $50 \mathrm{~km}$ in length. We speculate that the incision in the lower alluvial reaches around Kodai was caused by the eustatic lowering of the sea level.

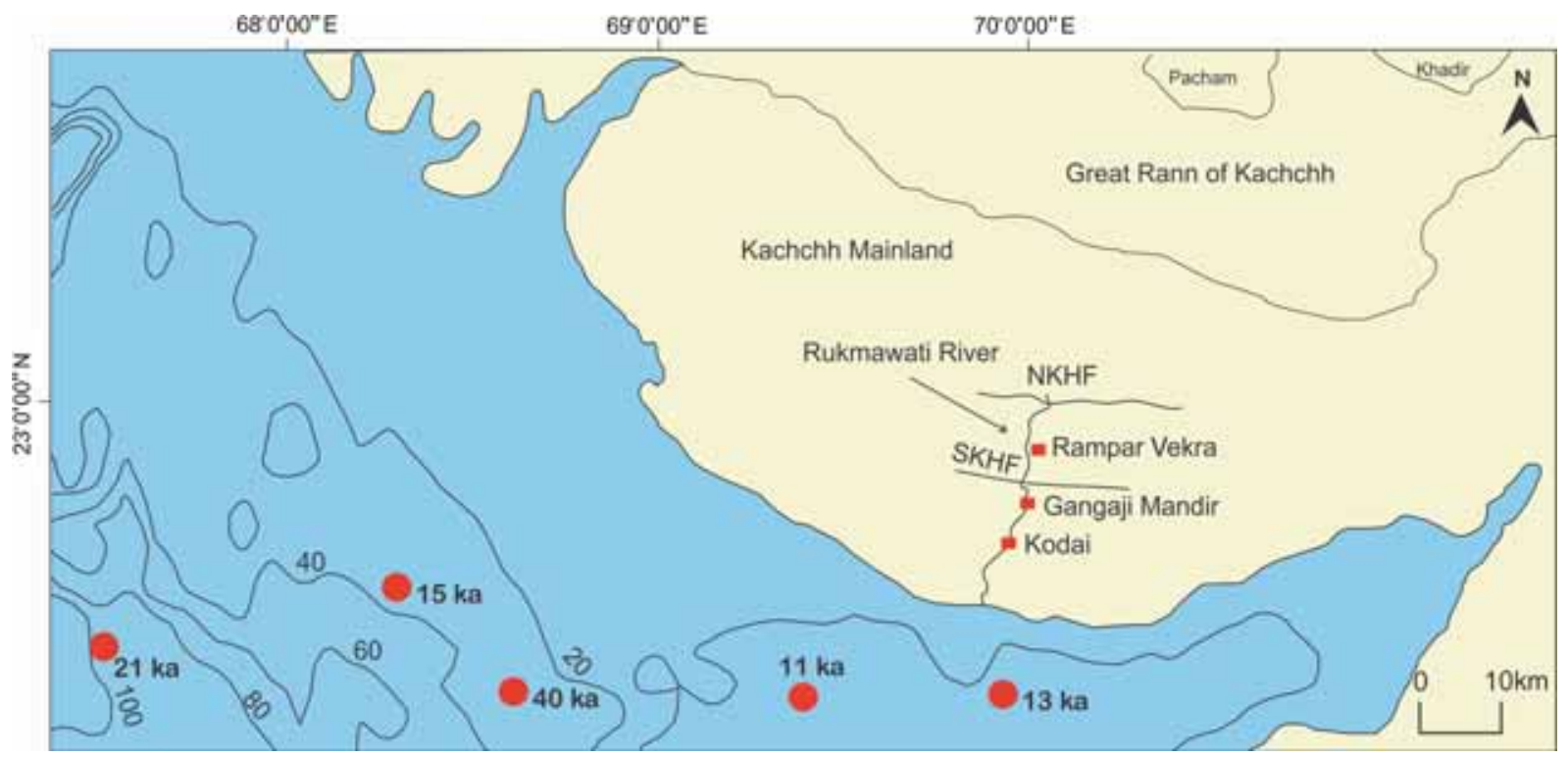

Figure 11. Bathymetry map of the western shelf of India with the locations from the Rukmawati River basin along with radiocarbon dates of carbonate sediments from the Gulf of Kachchh suggested by Rao et al. (2003). 
As compared to this, in the upland reaches, viz., around Rampar Vekra and Gangaji Mandir, tectonic activity along the NKHF and SKHF is implicated for the bedrock incision. Thus, summarising the observations, it is hypothesised that the aggradation was climatically modulated since $37 \mathrm{ka}$, however, the incision which began after 11 ka was a cumulative contribution of enhanced bedrock uplift (in the upper reaches) after $11 \mathrm{ka}$ and sea level lowering in the southern alluvial plain.

\section{Conclusion}

The following inferences can be drawn based on the field stratigraphy, sedimentology and optical chronology.

- The oldest sediment along the southern part of the KHF is dated to $37 \mathrm{ka}$, which was deposited by the braided meandering river system, due to the enhanced monsoon conditions corresponding to the later part of the MIS-3. This is followed by the declining monsoon, bracketing the LGM, mostly deposited as debris flows during $20 \mathrm{ka}$. The onset of the ISM and gradual strengthening of ISM with fluctuations is suggested between 15 ka and 11 ka.

- Based on the sedimentology and chronology, it may be suggested that the beveling of the Mesozoic bedrock occurred prior to or around $20 \mathrm{ka}$ due to enhanced uplift. The long-term uplift rate along the upstream and middle segment is estimated to be 0.8 and $0.3 \mathrm{~mm} / \mathrm{a}$. The values of geomorphic indices broadly indicate two uplifted segments (NKHF and SKHF).

- The incision after 11 ka was governed by the combination of enhanced bedrock uplift in the upper reaches and lowered sea level in the southern alluvial plain.

\section{Acknowledgements}

We thank the Department of Science and Technology, Government of Gujarat for financial assistance. We also thank Tarun Solanki and Girish Kothyari for the help in drawing some of the figures. We are also thankful to the anonymous reviewers for their productive comments which helped improve the earlier version of the paper. AD would like to thank Sumer Chopra for his constructive comments and valuable discussion.

\section{Appendix}

\section{Methodology of OSL}

The samples from freshly exposed sections were collected in aluminium pipes from five sedimentary units, i.e., unit-2 and 8 at Rampar Vekra; unit-2 at Gangaji Mandir and unit-4 and 6 at Kodai (figure 3a). The samples from both the ends of the tube, probably exposed to daylight during sampling, were removed. The samples were treated with $10 \% \mathrm{HCl}$ and $30 \% \mathrm{H}_{2} \mathrm{O}_{2}$ to remove the carbonates and the organic matters respectively. Following this, samples were dry sieved to obtain a 90-150 $\mu \mathrm{m}$ size fraction. This fraction was then treated with $40 \% \mathrm{HF}$ acid for $80 \mathrm{~min}$ to remove the outer alpha-irradiated skin of the quartz grain with continuous stirring and then treated with $12 \mathrm{~N}$ HCL for $30 \mathrm{~min}$ to remove any precipitated fluorides and then re-sieved to $>90 \mu \mathrm{m}$. The magnetic grains were removed and pure quartz is extracted by applying a magnetic field of 10,000 gauss using a Frantz Magnetic separator (Model LB1). The etched grains were mounted as a monolayer on stainless steel discs using Silkospray ${ }^{\mathrm{TM}}$. The feldspar purity was checked by infrared stimulation (IRSL), at room temperature. For every sample, a minimum of three natural aliquots were used. The samples were considered pure when IRSL to blue-light stimulated luminescence remained $<10 \%$. The samples failing the IRSL test were reetched for $30 \mathrm{~min}$ by $40 \% \mathrm{HF}$. All luminescence measurements were carried out using a Ris $\varnothing$ TADA-15 reader. The detection optics comprises of U-340 and BG-39 filters. Beta irradiations were carried out with a $25 \mathrm{mCi}{ }^{90} \mathrm{Sr} /{ }^{90} \mathrm{Y}$ source (radiation dose $7.86 \pm 62 \mathrm{~Gy} / \mathrm{min})$. The elemental concentrations of uranium, thorium and potassium were estimated using high-purity germanium detector. The cosmic ray estimation is based on the protocol suggested by Prescott and Hutton (1994) (table 1a) where $10 \pm 2 \%$ water content is assumed.

A conventional Single Aliquot Regeneration (SAR) protocol was used for estimating De (Murray and Wintle 2000). In SAR protocol, OSL measurement of the natural and regeneration doses $\left(\mathrm{L}_{\mathrm{x}}\right)$ is divided by OSL response to their respective test doses $\left(T_{x}\right)$. The regenerative doses are chosen in such a way that the corresponding sensitivitycorrected luminescence responses $\left(\mathrm{L}_{\mathrm{x}} / \mathrm{T}_{\mathrm{x}}\right)$ encompass the natural corrected luminescence $\left(\mathrm{L}_{n} / \mathrm{T}_{\mathrm{n}}\right)$. De is then obtained through interpolation. A preheat of $240^{\circ} \mathrm{C}$ for $10 \mathrm{sec}$ was used, whereas the cut heat was $200^{\circ} \mathrm{C}$ for $0 \mathrm{~s}$.

\section{References}

Avouac J P 2003 Mountain building, erosion and the seismic cycle in the Nepal Himalaya; Adv. Geophys. 46 1-79.

Aziz H A, Rubio E S, Calvo J P, Hilgen F J and Krijgsman W 2003 Palaeoenvironmental reconstruction of a middle Miocene alluvial fan to cyclic shallow lacustrine depositional system in the Calatayud Basin (NE Spain); Sedimentology 50 211-236. 
Bhattacharya F, Rastogi B K, Ngangom M, Thakkar M G and Patel R C 2013 Late Quaternary climate and seismicity in the Katrol Hill Range, Kachchh, western India; J. Asian Earth Sci. 73 114-120.

Bhattacharya F, Rastogi B K, Thakkar M G, Patel R C and Juyal N 2014 Fluvial landforms and their implication towards understanding the past climate and seismicity in the northern Katrol Hill Range, western India; Quat. Int. $33349-61$.

Biswas S K 2005 A review of structure and tectonics of Kutch basin, western India, with special reference to earthquakes; Curr. Sci. 88 1592-1600.

Blum M D and Valastro Jr. S 1994 Late Quaternary sedimentation, lower Colorado River, Gulf Coastal Plain of Texas; Geol. Soc. Am. Bull. 106 1002-1016.

Burbank D W, Leland J, Fielding E, Anderson R S, Brozovic N, Reid M R and Duncan C 1996 Bedrock incision, rock uplift, and threshold hillslopes in the north-western Himalayas; Nature 379 505-510.

Candy I, Black S and Sellwood B W 2004 Interpreting the response of a dryland river system to Late Quaternary climate change; Quat. Sci. Rev. 23 2513-2523.

Chamyal L S, Maurya D M and Rachna R 2003 Fluvial systems of the drylands of western India: A synthesis of Late Quaternary environmental and tectonic changes; Quat. Int. 104 69-86.

Chauhan O S, Borole D V, Gujar A R, Antonio M, Mislanker P G and Rao C M 1993 Evidences of climatic variations during Late Pleistocene-Holocene in the eastern Bay of Bengal; Curr. Sci. 65 558-562.

Chung W Y and Gao H 1995 Source parameters of the Anjar earthquake of July 21, 1956, India and its seismotectonic implications for the Kachchh rift basin; Tectonophys. 242 281-292.

Das A, Chauhan G, Prizomwala S P, Thakkar M G and Rastogi B K 2016 Geomorphic evidence and tectonic variability along the South Katrol Hill Fault, Kachchh, western India: Insights from geomorphic indices; $Z$. Geomorphol. (in press).

Dorsey R J and Roering J J 2006 Quaternary landscape evolution in the San Jacinto fault zone, peninsular ranges of southern California: Transient response to strike-slip fault initiation; Geomorphology 73 16-32.

Duplessy J C 1982 Glacial to interglacial contrast in the northern Indian Ocean; Nature 295 494-498.

Eppes M, Bierma R, Vinson D and Pazzaglia F 2008 A soil chronosequence study of the Reno River Valley, Italy; Geoderma 147(3) 97-107.

Fairbanks R G 1989 A 17,000 year glacio-eustatic sea level record: Influence of glacial melting rates on the Younger Dryas event and deep-ocean circulation; Nature 342 637-642.

Galbraith R F and Laslett G M 1993 Statistical models for mixed fission track ages; Radiat. Meas. 21 459-470.

Galbraith R F, Roberts R G, Laslett G M, Yoshida H and Olley J M 1999 Optical dating of single and multiple grains of quartz from Jinmium Rock Shelter, Northern Australia: Part I. Experimental design and statistical models; Archaeometry 41 339-364.

Garzione C N, DeCelles P G, Hodkinson D G, Ojha T P and Upreti B N 2003 East-west extension and Miocene environmental change in the southern Tibetan plateau: Thakkholagraben, central Nepal; Geol. Soc. Am. Bull. 115 3-20.

Goudie A S 1983 Chemical sediments and geomorphology: Precipitates and residua in the near-surface environment; Academic Press, London, pp. 93-132.

Griffiths P G, Webb R H and Melis T S 2004 Frequency and initiation of debris flows in Grand Canyon, Arizona; J. Geophys. Res. 109 F04002.
Gupta S K 1975 Silting of the Rann of Kachchh during Holocene; Indian J. Earth Sci. 2 163-175.

Hancock G S and Anderson R S 2002 Numerical modeling of fluvial strath-terrace formation in response to oscillating climate; Geol. Soc. Am. Bull. 114 1131-1142.

Hashimi N H, Nigam R, Nair R R and Rajagopalan G 1995 Holocene sea level fluctuations on western Indian continental margin: An update; J. Geol. Soc. India 46 $157-162$.

Hassan M A 1990 Scour, fill and burial depth of coarse material in gravel bed streams; Earth Surf. Proc. Land. 15 $341-356$.

Hein F J and Walker R G 1977 Bar evolution and development of stratification in the gravelly, braided, Kicking Horse River, British Columbia; Canadian J. Earth Sci. $14562-570$.

Iverson R M 1997 The physics of debris flows; Rev. Geophys. $35245-266$.

Jain M and Tandon S K 2003 Fluvial response to Late quaternary climate changes, western India; Quat Sci. Rev. 22 2223-2235.

Juyal N, Rachna R, Maurya D M, Chamyal L S and Singhvi A K 2000 Chronology of Late Pleistocene environmental changes in the lower Mahi basin, western India; J. Quat. Sci. 15 501-508.

Juyal N, Chamyal L S, Bhandari S, Bhushan R and Singhvi A K 2006 Continental record of the southwest monsoon during the last 130 ka: Evidence from the southern margin of the Thar Desert, India; Quat. Sci. Rev. 25 2632-2650.

Juyal N, Sundriyal Y P, Rana N, Chaudhary Shipra and Singhvi A K 2010 Late quaternary aggradation and incision in the monsoon-dominated Alaknanda valley, central Himalaya, Uttrakhand, India; J. Quat. Sci. 25 1293-1304.

Kale V S and Rajaguru S N 1987 Late Quaternary alluvial history of the northwestern Deccan upland region; Nature $325612-614$.

Kallmeier E, Breitkreuz C, Kiersnowski H and Geisler M 2010 Issues associated with the distinction between climatic and tectonic controls on Permian alluvial fan deposits from the Kotzen and Barnim Basins (North German Basin); Sedim. Geol. 223 15-34.

Keller A and Pinter N 1996 Active tectonics, earthquakes, uplift and landscape; Prentice-Hall, 1e237p.

Knighton D and Nanson G 1997 Distinctiveness, diversity and uniqueness in arid zone river systems; In: Arid Zone Geomorphology: Process, Form and Change in Drylands (ed) Thomas D S G, Wiley, Chichester, pp. 185-204.

Knox J C 1975 Concept of the graded stream; In: Theories of landform development (eds) Melhorn W N and Flemal $\mathrm{R} \mathrm{C}$, Proceedings of the 6th annual Binghamton Symposium, Publications in Geomorphology, State University of New York, Binghamton, NY, pp. 169-198.

Koss J E, Ethridge F G and Schumm S A 1994 An experimental study of the effects of base-level changes on fluvial, coastal plain systems; J. Sedim. Res. B 64 90-98.

Kraus J M 1997 Lower Eocene alluvial palaeosol: Pedogenic development, stratigraphy relationship and paleo-landscape association; Palaeogeogr. Palaeoclimatol. Palaeoecol. 129 387-406.

Kundu H K, Thakkar M G, Biswas R H and Singhvi A K 2010 Optical dating of sediments in Khari river basin and slip rate along Katrol Hill Fault (KHF), Kachchh, India; Geochronometria 37 21-28.

Lambeck K and Chappell J 2001 Sea level change through the last glacial cycle; Science 292 679-685. 
Lave J and Avouac J P 2001 Fluvial incision and tectonic uplift across the Himalayas of central Nepal; J. Geophys. Res.-Sol. Ea. 106 26,561-26,591.

Mathew G, Singhvi A K and Karanth R V 2006 Luminescence chronometry and geomorphic evidence of active fold growth along the Kachchh Mainland Fault (KMF), Kachchh, India: Seismotectonic implications; Tectonophys. 422 71-87.

Mathur U B 2005 Quaternary geology: Indian perspective (with notes on Quaternary of Gujarat); Geol. Soc. India 63344.

Maurya D M, Thakkar M G and Chamyal L S 2003 Implications of transverse fault system on tectonic evolution of Mainland Kachchh, western India; Curr. Sci. 85 661-667.

Maurya D M, Thakkar M G, Patidar A K, Bhandari S, Goyal B and Chamyal L S 2008 Late Quaternary geomorphic evolution of the coastal zone of Kachchh, western India; J. Coast. Res. 24 746-758.

Miall A D 1988 Stratigraphy sequences and their chronostratigraphic correlation; J. Sedim. Petrol. 61 497-505.

Miall A D 1996 The geology of fluvial deposits; Springer, Berlin, 582p.

Morino M, Malik J N, Mishra P, Bhuiyan C and Kaneko F 2008 Active fault traces along Bhuj Fault and Katrol Hill Fault, and trenching survey at Wandhay, Kachchh, Gujarat, India; J. Earth Syst. Sci. 117 181-188.

Murray A S and Wintle A G 2000 Luminescence dating of quartz using an improved single-aliquot regenerative dose protocol; Radiat. Meas. 32 57-73.

Nanson G C and Tooth S 1999 Arid-zone rivers as indicators of climate change; In: Paleoenvironmental Reconstruction in Arid Lands (eds) Singhvi A K and Derbyshire E (Balkema: Rotterdam), pp. 175-216.

Overpeck J, Anderson D, Trumbore S and Prell W 1996 The southwest Indian monsoon over the last 18,000 years; Clim. Dyn. 12(3) 213-225.

Pant R K and Chamyal L S 1990 Quaternary sedimentation pattern and terrain evolution in the Mahiriver, Gujarat, India; Proc. Indian Nat. Sci. Acad. 56 501-511.

Patidar A K, Maurya D M, Thakkar M G and Chamyal L S 2007 Fluvial geomorphology and neotectonic activity based on field and GPR data, Katrol Hill Range, Kachchh, western India; Quat. Int. 159 74-92.

Patidar A K, Maurya D M, Thakkar M G and Chamyal L S 2008 Evidence of neotectonics reactivation of the Katrol Hill Fault during Late Quaternary and its GPR characterization; Curr. Sci. 94 338-346.

Pope R, Wilkinson K, Skourtsos E, Triantaphyllou M and Ferrier G 2008 Clarifying stages of alluvial fan evolution along the Sfakian piedmont, southern Crete: New evidence from analysis of post-incisive soils and OSL dating; Geomorphology 94 206-225.

Pramanik S K 1952 Hydrology of the Rajasthan Desert: Rainfall, humidity and evaporation; In: Proceedings Symposium Rajputana Desert, National Institute of Science, India, pp. 183-197.

Prasad V, Farooqui A, Sharma A, Phartiyal B, Chakraborty S, Bhandari S, Raj R and Singh A 2014 Mid-late Holocene monsoonal variations from mainland Gujarat, India: A multi-proxy study for evaluating climate culture relationship; Palaeogeogr. Palaeoclimatol. Palaeoecol. 397 38-51.

Prell W L and Kutzbach J E 1987 Monsoon variability over the past 150,000 years; J. Geophys. Res. 92 8411-8425.
Prescott J R and Hutton J T 1994 Cosmic ray contributions to dose rates for luminescence and ESR dating: Large depths and long term variations; Radiat. Meas. 23 497-500.

Prizomwala S P, Solanki T, Chauhan G, Das A, Bhatt N P, Thakkar M G and Rastogi B K 2016a Spatial variations in tectonic activity along the Kachchh Mainlan Fault, Kachchh, western India: Implications in seismic hazard assessment; Nat. Hazards $\mathbf{8 2 ( 2 )}$ 947-961.

Prizomwala S P, Das A, Chauhan G, Solanki T, Basavaiah N, Bhatt N P, Thakkar M G and Rastogi B K 2016b Late Pleistocene-Holocene uplift driven terrace formation and climate-tectonic interplay from a seismically active intraplate setting: An example from Kachchh, western India; J. Asian Earth Sci. 124 55-67.

Rajenderan C P and Rajenderan Kushala 2001 Characteristics of deformation and past seismicity associated with the 1819 Kutch earthquake, northwestern India; B. Seismol. Soc. Am. 91 407-426.

Rao P C, Rajgopalan G, Vora K H and Almeida F 2003 Late Quaternary sea level and environmental changes from relic carbonate deposits of the western margin of India; Proc. Indian Acad. Sci. (Earth Planet. Sci.) 112 $1-25$.

Rastogi B K, Kumar S and Aggrawal S K 2012 Seismicity of Gujarat; Nat. Hazards 65(2) 1027-1044.

Reid I and Frostick L E 1997 Channel forms, flow and sediment in deserts; In: Arid Zone Geomorphology (ed.) Thomas D S G, Wiley, Chichester, pp. 205-229.

Schulz H, Rad V U and Erlenkeuser H 1998 Correlation between Arabian Sea and Greenland climate oscillations of the past 110,000 years; Nature 398 54-57.

Schumm S A 1993 River response to base level change: Implications for sequence stratigraphy; J. Geol. 101 279-294.

Schumm S A and Brakenridge G R 1987 River responses; In: North America and adjacent oceans during the last deglaciation; Geol. Soc. Am. 3 221-240.

Singh I B, Sharma S, Sharma M, Srivastava P and Rajagopalan G 1999 Evidence of human occupation and humid climate of $30 \mathrm{ka}$ in the alluvium of southern Ganga Plain; Curr. Sci. 76 1022-1026.

Sontakke N A, Singh H N and Singh N 2008 Chief features of physiographic rainfall variations across India during instrumental period (1813e2006); Contribution from IITM Research Report, N. RR 121, ISSN: 0252-1075 128.

Srivastava P, Juyal N, Singhvi A K and Wasson R J 2001 Luminescence chronology of river adjustment and incision of Quaternary sediments in the alluvial plains of Sabarmati River, north Gujarat, India; Geomorphology 36 $217-229$.

Tandon S K, Sareen B K, Someshwara Rao M and Singhvi A K 1997 Aggradation history and luminescence chronology of Late Quaternary semi-arid sequences of the Sabarmati basin, Gujarat, western India; Palaeogeogr. Palaeoclimatol. Palaeoecol. 128 339-357.

Thakkar M G, Goyal B, Patidar A K, Maurya D M and Chamyal L S 2006 Bedrock gorges in the central Mainland Kachchh: Implications for landscape evolution; J. Earth Syst. Sci. 115 1-8.

Thomas P J, Juyal N, Kale V S and Singhvi A K 2007 Luminescence chronology of late Holocene extreme hydrological events in the upper Penner river basin, south India; J. Quat. Sci. 22 747-753.

Thompson L G, Yao T, Davis M E, Henderson K A, MoslyThompson E, Lin P N, Beer J, Synal H A, Cole-Dai J and Bolzan J F 1997 Tropical climate instability: The last 
glacial cycle from a Quinghai-Tibetan ice core; Science 276 1821-1825.

Tooth S 2000 Process, form and change in dryland rivers: A review of recent research; Earth-Sci. Rev. 51 67-107.

Waclawik V G, Lang S C and Krapf C B E 2008 Fluvial response to tectonic activity in an intra-continental dryland setting: The Neales River, Lake Eyre, Central Australia; Geomorphology 102 179-188.

Wasson R J 1979 Stratified debris slope deposits in the Hindu Kush, Pakistan; Z. Geomorphol. 23 301-320.

Whipple K X 2004 Bedrock Rivers and the geomorphology of active orogens; Ann. Rev. Earth Planet. Sci. 32 151-185.

MS received 13 August 2015; revised 26 May 2016; accepted 5 June 2016

Corresponding editor: N V ChALAPATHI RAO 